\title{
SIX2 and SIX3 coordinately regulate functional maturity and fate of human pancreatic $\beta$ cells
}

\author{
Romina J. Bevacqua, ${ }^{1}$ Jonathan Y. Lam, ${ }^{1}$ Heshan Peiris, ${ }^{1}$ Robert L. Whitener, ${ }^{1}$ Seokho Kim, ${ }^{1}$ \\ Xueying Gu, ${ }^{1}$ Mollie S.H. Friedlander, ${ }^{1}$ and Seung K. Kim ${ }^{1,2,3}$ \\ ${ }^{1}$ Department of Developmental Biology, Stanford University School of Medicine, Stanford, California 94305, USA; ${ }^{2}$ Department of \\ Medicine (Endocrinology), Stanford University School of Medicine, Stanford, California 94305, USA; ${ }^{3}$ Stanford Diabetes Research \\ Center, Stanford University School of Medicine, Stanford, California 94305, USA
}

The physiological functions of many vital tissues and organs continue to mature after birth, but the genetic mechanisms governing this postnatal maturation remain an unsolved mystery. Human pancreatic $\beta$ cells produce and secrete insulin in response to physiological cues like glucose, and these hallmark functions improve in the years after birth. This coincides with expression of the transcription factors SIX2 and SIX3, whose functions in native human $\beta$ cells remain unknown. Here, we show that shRNA-mediated SIX2 or SIX3 suppression in human pancreatic adult islets impairs insulin secretion. However, transcriptome studies revealed that $S I X 2$ and $S I X 3$ regulate distinct targets. Loss of SIX 2 markedly impaired expression of genes governing $\beta$-cell insulin processing and output, glucose sensing, and electrophysiology, while $S I X 3$ loss led to inappropriate expression of genes normally expressed in fetal $\beta$ cells, adult $\alpha$ cells, and other non- $\beta$ cells. Chromatin accessibility studies identified genes directly regulated by SIX2. Moreover, $\beta$ cells from diabetic humans with impaired insulin secretion also had reduced SIX2 transcript levels. Revealing how SIX 2 and SIX3 govern functional maturation and maintain developmental fate in native hu$\operatorname{man} \beta$ cells should advance $\beta$-cell replacement and other therapeutic strategies for diabetes.

[Keywords: $\beta$ cells; islet; transcription factor; diabetes mellitus; pancreas]

Supplemental material is available for this article.

Received July 7, 2020; revised version accepted December 8, 2020.

Development of vital organs, like the brain and pancreas, includes a prenatal stage when the embryonic organ anlage, specification, and expansion of major differentiated cell types, organ morphology, and anatomic position are established, followed by a postnatal stage when differentiated cell types acquire mature physiological functions and refine their cellular interactions (Reinert et al. 2014; Kim et al. 2020). Improved understanding of the mechanisms underlying postnatal "functional maturation" in cells like pancreatic islet cells could accelerate efforts to improve therapies for diabetes, including production of replacement human $\beta$ cells from renewable sources (Arda et al. 2016, 2018; Bakken et al. 2016; Sneddon et al. 2018).

During prenatal and neonatal stages, islet $\beta$ cells transiently proliferate and expand. In childhood and thereafter, $\beta$ cells reduce proliferation (Teta et al. 2005; Meier et al. 2008; Wang et al. 2016a), increase insulin production, and enhance glucose-dependent insulin secretion, all hallmarks of mature $\beta$-cell function (Artner et al. 2007, 2010; Aguayo-Mazzucato et al. 2011; Arda et al.

Corresponding author: seungkim@stanford.edu Article published online ahead of print. Article and publcation date are online at http://www.genesdev.org/cgi/doi/10.1101/gad.342378.120.
2016). The genetic and molecular mechanisms governing this age-dependent $\beta$-cell functional maturation are intensely sought. Prior studies in mice suggest that transcription factors (TFs) regulate functional maturation of $\beta$ cells (Aguayo-Mazzucato et al. 2011; Lantz et al. 2004; Schaffer et al. 2013; Yoshihara et al. 2016). However, less is known about the role of TFs in human $\beta$-cell maturation, reflecting the challenges of studying postnatal development in native human $\beta$ cells. Mutations in genes encoding TFs including PDX1, NEUROD1, MAFA, GATA6, and RFX6 have been linked to monogenic forms of diabetes mellitus and impaired $\beta$-cell function in humans, suggesting roles in $\beta$-cell maturation (for reviews, see Sellick et al. 2004; Allen et al. 2012; Patel et al. 2017; Iacovazzo et al. 2018; Urakami 2019). Thus, TFs may represent a class of factors governing age-dependent postnatal $\beta$-cell functional maturation in humans.

(C) 2021 Bevacqua et al. This article is distributed exclusively by Cold Spring Harbor Laboratory Press for the first six months after the full-issue publication date (see http://genesdev.cshlp.org/site/misc/terms.xhtml). After six months, it is available under a Creative Commons License (Attribution-NonCommercial 4.0 International), as described at http://creativecommons.org/licenses/by-nc/4.0/. 
We and others have found that SIX2 and SIX3, members of the sine oculis homeobox family of TFs, are first expressed in the $\beta$ cells of children by 9-10 yr of age (Blodgett et al. 2015; Arda et al. 2016; Wang et al. 2016b; Cyphert et al. 2019), followed by increased expression in adulthood. Moreover, neither SIX2 nor SIX3 mRNA are detectable in human a cells (Blodgett et al. 2015; Arda et al. 2016; Wang et al. 2016b). SIX2 and SIX3 are encoded by linked genes on human chromosome 2 (OMIM: 604994 and 603714). While they show high homology in their N-terminal SIX domain and their central homeodomain (HD), other portions of SIX2 and SIX3 differ (Kawakami et al. 2000) and could mediate distinct interactions. For example, SIX3, but not SIX2, interacts with members of the groucho family of corepressors (Kobayashi et al. 2001; López-Ríos et al. 2003). In addition, SIX2 has roles in development of kidneys, skull, stomach, and other organs (Kobayashi et al. 2008; Self et al. 2009; He et al. 2010; Park et al. 2012), while SIX3 has roles in forebrain and eye development (Jeong et al. 2008; Liu et al. 2010).

SIX2 and SIX3 have largely nonoverlapping tissue expression patterns that correspond with their distinct roles in human organogenesis. In the pancreas, however, both SIX2 and SIX3 are expressed in human $\beta$ cells, with coincident onset of postnatal expression and a shared cis-regulatory element that coregulates islet SIX2 and SIX3 expression (Spracklen et al. 2018). This element encompasses single nucleotide polymorphisms (SNPs) associated with type 2 diabetes (T2D) and fasting hyperglycemia (Kim et al. 2011; Spracklen et al. 2020). Nevertheless, it remains unknown whether SIX2 and SIX3 are required for normal adult $\beta$-cell function, what $\beta$-cell genes these TFs regulate, and whether their expression is altered in diabetes.

Prior studies suggest that SIX2 or SIX3 might regulate genes with roles in restricting native $\beta$-cell proliferation and enhancing insulin production and secretion. The onset of SIX2 and SIX3 expression in postnatal human $\beta$ cells temporally coincides with age-dependent enhancement of insulin production and secretion (Blodgett et al. 2015; Arda et al. 2016). Moreover, misexpression of SIX3 in immature islets from children stimulated glucose-dependent insulin secretion (Arda et al. 2016). Neither SIX2 nor SIX3 is expressed in mouse islets (Benner et al. 2014; Baron et al. 2016); thus, loss-of-function studies that clearly identify requirements for SIX 2 or SIX3 in $\beta$-cell function will require studies in native human islets or alternative experimental systems. Attempts to generate insulin-secreting $\beta$ cells from human stem cells have only produced immature progeny that express SIX2, often at low levels, and fail to express SIX3 (Sneddon et al. 2018; Nair et al. 2019; Veres et al. 2019; Velazco-Cruz et al. 2020). To overcome these limitations, here we investigated SIX2 and SIX3 in adult human islets, using recently described genetic methods permitting targeted loss of function in primary human islets (Peiris et al. 2018). Controlled islet cell dispersion and reaggregation to develop human "pseudoislets" (Scharp et al. 1980; Tze and Tai 1982; Arda et al. 2016) allowed us to achieve shRNA-mediated SIX2 or SIX3 suppression in human adult $\beta$ cells. Collectively, these studies demonstrate that SIX2 and SIX 3 coordinately regulate distinct genetic programs in human $\beta$ cells, including expression of target genes governing mature $\beta$-cell function and maintaining $\beta$-cell fate. Moreover, we show that SIX2 expression is reduced in $\beta$ cells purified from human donors with T2D and impaired islet insulin secretion, suggesting roles for SIX2 in the pathogenesis of $\beta$-cell defects in T2D.

\section{Results}

Reduced SIX2 or SIX3 expression impairs regulated insulin secretion by human islets

We used RNAi-based strategies to reduce SIX2 or SIX3 mRNA levels in primary human adult islets. After dispersion of primary islets, lentiviral transduction was used to achieve shRNA-mediated suppression of SIX2 or SIX3 (hereafter, $S I X 2^{\mathrm{kd}}$ or $S I X 3^{\mathrm{kd}}$ ) and to simultaneously express a GFP transgene (Peiris et al. 2018), followed by reaggregation into pseudoislets (Fig. 1A,B; Materials and Methods). We used immunostaining to detect $\beta$ cells (insulin [INS]), a cells (glucagon [GCG]), and $\delta$ cells (somatostatin [SST]) in pseudoislets, and verified reaggregation of these principal islet cell types in appropriate proportions (Supplemental Fig. S1). Five days after lentiviral infection, we confirmed significant reduction of SIX2 or SIX3 in pseudoislets by qRT-PCR (Fig. 1C,D; Materials and Methods). In contrast, we did not detect altered SIX3 mRNA levels after $S I X 2^{\mathrm{kd}}$ or altered SIX2 mRNA levels after $S I X 3^{\mathrm{kd}}$ (Fig. 1E,F), providing evidence that SIX2 and SIX3 expression are not mutually cross-regulated.

We subsequently assessed glucose-stimulated insulin secretion (GSIS) following SIX $2^{\mathrm{kd}}$ or SIX $3^{\mathrm{kd}}$ in primary human pseudoislets. Like in our prior studies (Peiris et al. 2018), control pseudoislets infected with lentivirus expressing nontargeting shRNA ("control") showed a significant increase in insulin secretion after a glucose step increase from 2.8 to $5.6 \mathrm{mM}, 16.7 \mathrm{mM}, 25 \mathrm{mM}$, or $25 \mathrm{mM}$ glucose supplemented with the secretion potentiator IBMX (Fig. 1G,I). By comparison, insulin secretion by pseudoislets after SIX $2^{\mathrm{kd}}$ was significantly blunted in 2.8 and $16.7 \mathrm{mM}$ glucose and trended toward reduction at 5.6 $\mathrm{mM}$ (Fig 1G). Likewise, after SIX $3^{\mathrm{kd}}$, there was significant blunting of insulin secretion in 2.8,5.6, 16.7, and $25 \mathrm{mM}$ glucose (Fig. 1I). GSIS data were normalized to total pseudoislet insulin content, which was not significantly altered after $\operatorname{SIX}^{\mathrm{kd}}$ (Fig. 1H) or SIX3 ${ }^{\mathrm{kd}}$ (Fig. 1J). This suggests that reduced insulin release from islets after $S I X 2^{\mathrm{kd}}$ or $S I X 3^{\mathrm{kd}}$ reflects impaired secretion. Together, our findings provide index evidence that reduced SIX 2 or SIX3 function impairs human adult islet $\beta$-cell function.

\section{Elucidating the SIX2-dependent adult $\beta$-cell transcriptome}

SIX2 is an established transcriptional regulator (Kobayashi et al. 2008; Self et al. 2009; He et al. 2010; Park et al. 2012), but SIX2-dependent genetic targets in adult islet $\beta$ cells are unknown. To identify genes regulated by SIX 2 , we purified 
A

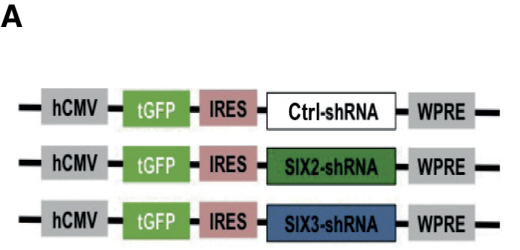

B Intact Primary Human islets
Pseudoislets

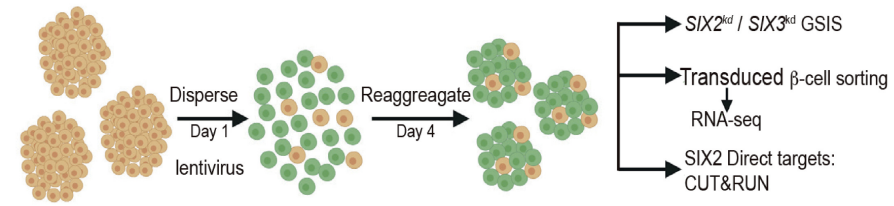

C

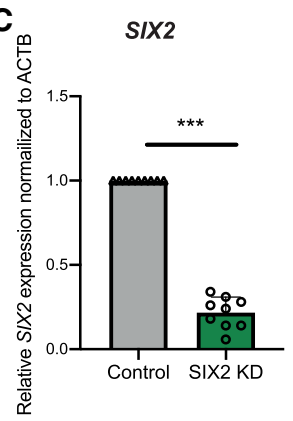

D

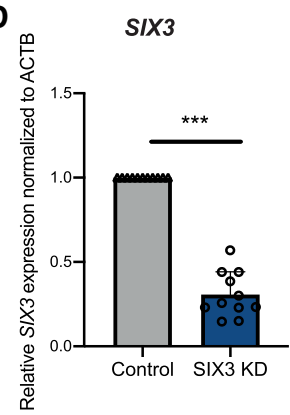

E

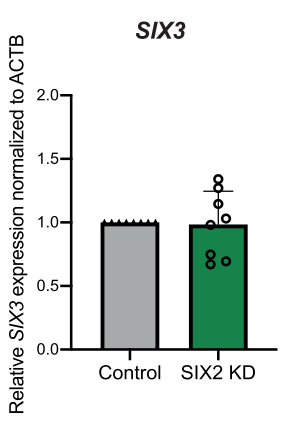

F

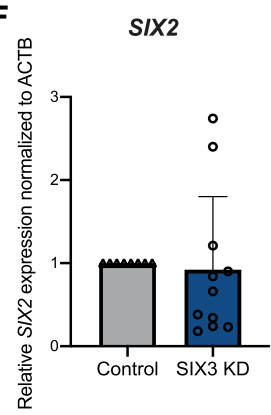

G

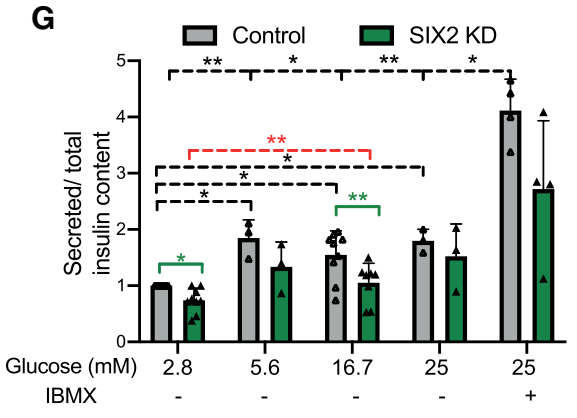

H

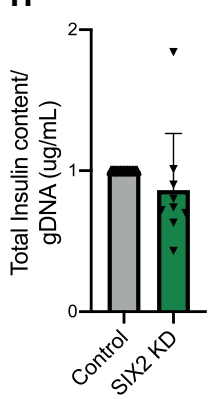

I

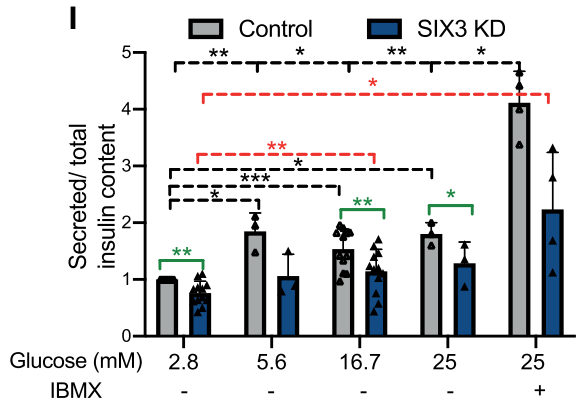

J

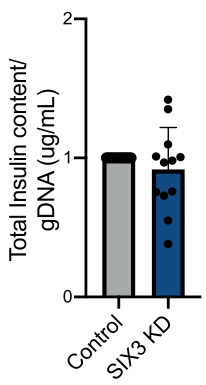

Figure 1. shRNA-mediated suppression of SIX2 and SIX3 in primary human islets results in impaired glucose-stimulated insulin secretion. (A) Schematics of the lentiviral constructs coding for a short hairpin RNA (shRNA) and GFP. (B) Schematic detailing the pseudoislet technique. (C) SIX2 mRNA expression in primary human islets. (Gray bar) Control, (green bar) SIX $2^{\mathrm{kd}} . n=9$ independent donor repetitions. (D) SIX3 mRNA expression in primary human islets. (Gray bar) Control, (blue bar) $S I X 3^{\mathrm{kd}} . n=11$ independent donor repetitions. $S I X 3$ mRNA were not altered by $S I X 2^{\mathrm{kd}}\left(n=8\right.$ independent donor repetitions) (E), and SIX2 mRNA levels were not affected by $S I X 3^{\mathrm{kd}}$ $\left(n=11\right.$ independent donor repetitions) $(F) .(G, I)$ In vitro glucose-stimulated insulin secretion from human pseudoislets control, SIX $2^{\mathrm{kd}}$ $\left(n=9\right.$ independent donor repetitions) $(G)$, or $S I X 3^{\mathrm{kd}}(n=12$ independent donor repetitions) $(I)$. Secreted insulin normalized to insulin content. (Black lines) Significant differences within the control, (red lines) significant differences within the KD groups, (green lines) significant differences between control and KD conditions. $(H, J)$ Total insulin from human pseudoislets after transduction with $S I X 2^{\mathrm{kd}}(n=9$ independent donor repetitions) $(H)$ or $S I X 3^{\mathrm{kd}}(n=12$ independent donor repetitions) $(J)$. Data presented as mean; error bars represent the standard error. Two-tailed $t$-tests used to generate $P$-values: $\left({ }^{*}\right) P<0.05,(* *) P<0.01,(* * *) P<0.0001$.

$\beta$ cells from pseudoislets after SIX2 ${ }^{\mathrm{kd}}$ (Fig. 2A-C; Materials and Methods). Intracellular labeling with antibodies against insulin and glucagon followed by flow cytometry and GFP gating (Fig. 2C; Supplemental Fig. S2A; Peiris et al. 2018) enriched for INS ${ }^{+}$GFP $^{+} \beta$ cells; qRT-PCR anal$y$ sis of this cell subset confirmed enrichment of mRNA encoding INS, and depletion of GCG, or of the acinar and ductal cell markers, CPA1 and KRT19 (Supplemental Fig. S2B). We verified efficient shRNA-mediated suppression of SIX2 in $\mathrm{INS}^{+} \mathrm{GFP}^{+} \beta$ cells compared with control $\mathrm{INS}^{+} \mathrm{GFP}^{+} \beta$ cells (Supplemental Fig. S2C). We then produced and sequenced RNA-seq libraries from SIX2 ${ }^{\mathrm{kd}}$ and control $\beta$ cells ( $n=4$ independent donors) (Materials and Methods). Pearson correlation and hierarchical clustering analysis revealed clustering of $S I X 2^{\mathrm{kd}}$ and control samples from the same donor (Supplemental Fig. S2D,E), reflecting the expected inter-donor variability we and others have previously reported (Arda et al. 2016; Segerstolpe et al. 2016; Enge et al. 2017; Peiris et al. 2018). We used the DE-Seq2 algorithm (Love et al. 2014) to identify differentially expressed (DE) genes following $S I X 2^{\mathrm{kd}}$. Expression of 1242 genes, including SIX2 itself, was significantly decreased after SIX2 ${ }^{\mathrm{kd}}$ (Fig. 2D,G; Supplemental Table S2), whereas expression of 928 genes was significantly increased $(P<0.05)$ (Fig. 2I; Supplemental Table S3). In contrast, we did not detect changes in expression of $\beta$-cell SIX3 upon SIX2 ${ }^{\mathrm{kd}}$ (Fig. 2E). Gene ontology (GO) term analysis (Fig. 2F) suggested unifying molecular functions in these enriched gene sets, including terms related to adult $\beta$-cell function, proliferation, and cell cycle regulation.

Genes with decreased expression in SIX2 ${ }^{\mathrm{kd}} \beta$ cells included those encoding cardinal $\beta$-cell factors like INS, 


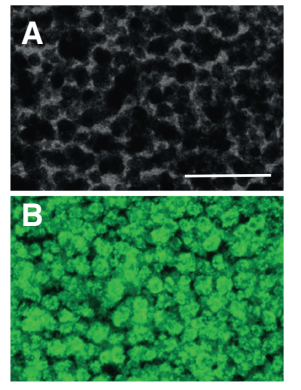

C

F

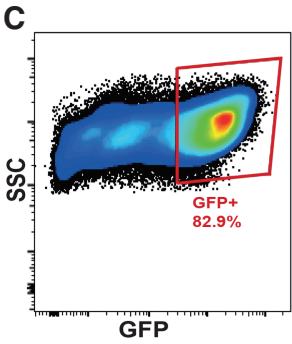

GO: All DE-genes

Regulation of hormone secretion -

Response to calcium ion

Carbohydrate homeostasis

Glucose Homeostasis

Cell proliferation

Regulation of Insulin secretion -

Regulation of cell cycle

Cell differentiation

Exocytosis

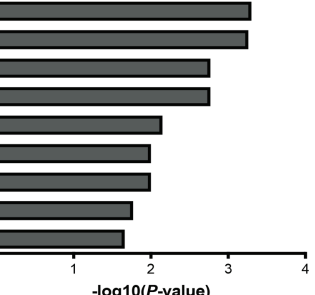

$-\log 10(P$-value $)$

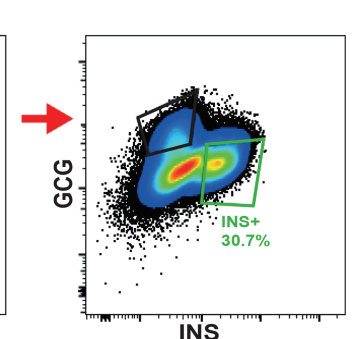

D

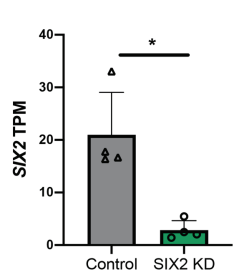

E

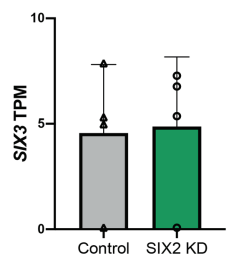

H

KEGG-pathways: downregulated genes

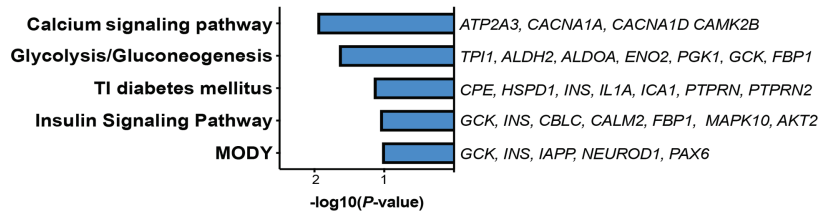

I

KEGG-pathways: upregulated genes

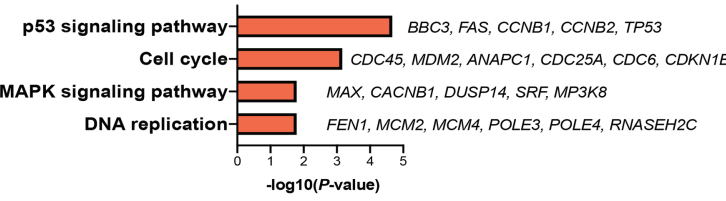

G

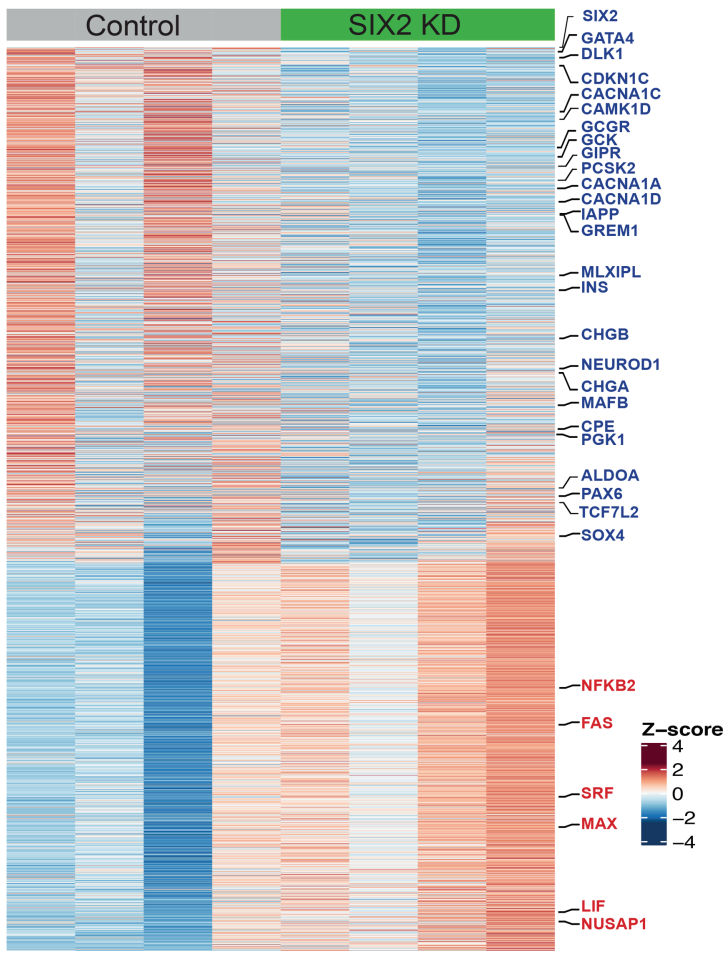

Figure 2. RNA-seq of $S I X 2^{\mathrm{kd}} \beta$ cells reveals genes regulated by SIX 2 in primary human islets. $(A, B) S I X 2^{\mathrm{kd}}$ human pseudoislets. $(A)$ Bright field. (B) Blue light $(488 \mathrm{~nm})$. Scale bars, $500 \mu \mathrm{m}$. (C) FACS scheme used to sort GFP+ $\beta$ cells. $(D, E)$ Normalized transcript levels of SIX2 (D) and $S I X 3(E)$ in GFP+ $\beta$-cells. (Gray bar) Control, (green bar) $S I X 2^{\mathrm{kd}} . n=4$. $(F)$ GO term enrichment in genes deregulated in $\beta$ cells post$S I X 2^{\mathrm{kd}} .(G, H)$ KEGG pathway enrichment in genes up-regulated $(G)$ or down-regulated $(H)$ in $\beta$ cells post-SIX2 ${ }^{\mathrm{kd}}(n=4)$. $(I)$ Heat map showing all differentially expressed (DE) genes in $\beta$ cells post-SIX $2^{\mathrm{kd}}$. The data are presented as mean; error bars represent the standard error. $(*) P<0.05$

CHGA, CHGB, and IAPP; insulin processing enzymes like $C P E$ and $P C S K 2$; and transcription factors like PAX6, NEUROD1, NKX6.1, MLXIPL, TCF7L2, ESRRG, and $M A F B$ (Fig. 2G,H; Supplemental Table S2). In addition, we noted severe reduction of mRNAs encoding glucokinase $(G C K)$, the principal sensor of glucose flux in $\beta$ cells (Matschinsky et al. 1993); glucagon receptor $(G C G R)$; regulators of glycolysis and $\beta$-cell stimulus secretion coupling encoded by TPI1, ALDH2, ALDOA, ENO2, $P G K 1$, and $F B P 1$; and $C A M K 1 D$, a postulated type 2 diabetes risk gene (Fig. 2G; Thurner et al. 2018; Miguel-Escalada et al. 2019). In contrast, we observed increased levels of mRNAs encoding regulators of DNA replication and cell cycle factors in $S I X 2^{\mathrm{kd}} \beta$ cells, including NUSAP1, MAX, and SRF (Fig. 2G,I). This is consistent with prior findings (Arda et al. 2016) providing evidence that SIX2 expression may enforce $\beta$-cell cycle arrest and studies linking $\beta$-cell cycle exit to enhanced function (Helman et al. 2016). GO and KEGG pathway analysis of DE genes (Materials and Methods) revealed significant enrichment of terms including regulation of hormone secretion, glucose homeostasis, calcium signaling, and insulin signaling (Fig. 2F,H,I). Thus, these data suggest that SIX2 is required to maintain hallmark adult $\beta$-cell functions involved with insulin production and processing, glucose sensing, and proliferation, and support our finding of impaired GSIS after $S I X 2^{\mathrm{kd}}$ in adult human islets.

To validate our findings further, we assessed whether genes regulated by $S I X 2^{\mathrm{kd}}$ were enriched in gene sets whose expression changed in $\beta$ cells expressing SIX2 (see the Materials and Methods; Blodgett et al. 2015; Arda et al. 2016). For example, we asked whether the set of 
genes with decreased expression after SIX2kd overlapped with DE genes whose mRNA normally increased with advancing age. In this case, we identified 287 genes with decreased expression after $S I X 2^{\mathrm{kd}}$ in $\beta$ cells, whose expression was significantly increased in SIX2 ${ }^{+}$adult $\beta$ cells compared with fetal or juvenile SIX $2^{\text {neg }} \beta$ cells $\left(P<3.873 \times 10^{-30}\right)$ (Fig. 3A,B; Supplemental Table S7). These included $C D K N 1 C$ and $C D K N 1 A$, which encode inhibitors of cell proliferation; CACNA1C and CACNA1D, which encode calcium channels; GCGR, which encodes a receptor for glucagon and the incretin GLP-1 (Svendsen et al. 2018); and MLXIPL (also known as ChREBP), a glucose-activated transcription factor that regulates GCGR (lizuka et al. 2012), GREM1, IAPP, and DLK1 (Fig. 3A,B; Supplemental Table S7). Based on similar logic, we identified 146 genes with significantly increased expression after $S I X 2^{\mathrm{kd}}$, whose expression is normally decreased in SIX2 ${ }^{+}$ adult $\beta$ cells $\left(P<5.2 \times 10^{-5}\right)$ (Fig. 3B; Supplemental Table S7; Blodgett et al. 2015; Arda et al. 2016). These included NUSAP1 and SRF, postulated regulators of islet cell proliferation (Zeng et al. 2017), and RFX7, a marker of pancreatic progenitor cells (Kim-Muller et al. 2016). We also compared

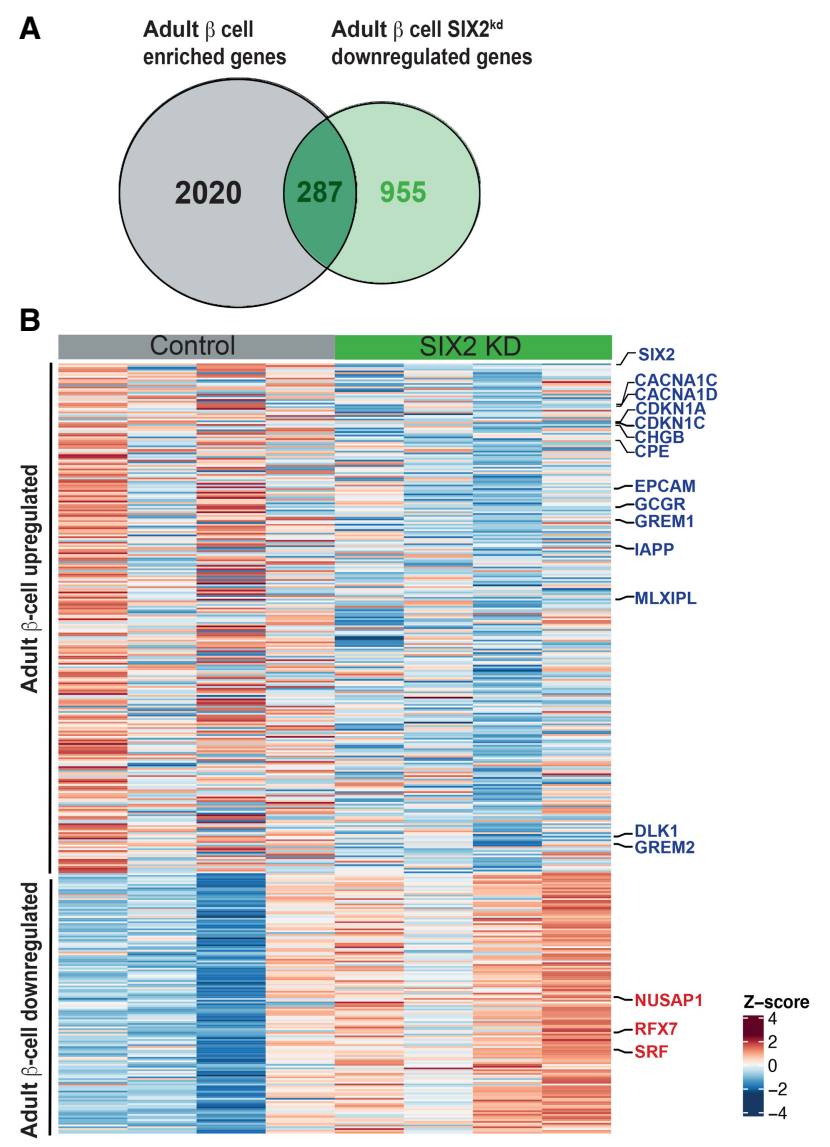

Figure 3. $S I X 2^{\mathrm{kd}}$ in primary $\beta$ cells results in down-regulation of genes enriched in adult $\beta$-cell. $(A)$ Venn diagram showing adult $\beta$-cell genes down-regulated post-SIX2 $2^{\mathrm{kd}}$. (B) Heat map of adult down-regulated genes and juvenile up-regulated genes in adult $\beta$ cells post-SIX2 $2^{\mathrm{kd}}$. this data set with DE transcriptomic data recently reported after SIX2 loss in $\beta$-like cells ("SC- $\beta$ ") generated from a human embryonic stem cell line (Velazco-Cruz et al. 2020). We found a general lack of concordance in DE genes (Materials and Methods): Specifically, we observed 30\% (377/ 1242) overlap of genes with reduced expression and $14 \%$ (132/928) overlap of genes with increased expression after SIX2 ${ }^{\mathrm{kd}}$ (Supplemental Fig. S3A,B; Supplemental Table S12). Many mRNAs that decreased after $S I X 2^{\mathrm{kd}}$ in native $\beta$ cells, like $M A F B, G I P R$, and GREM1, did not change after $S I X 2^{\mathrm{kd}}$ in SC- $\beta$ cells. Other mRNAs that decreased after $S I X 2^{\mathrm{kd}}$ in adult $\beta$ cells, like CDKN1C, GCGR, TCF7L2, and NKX6.1, were found increased after $S I X 2^{\mathrm{kd}}$ in SC- $\beta$ cells (Velazco-Cruz et al. 2020). These findings indicate that genetic programs in native human $\beta$ cells and SC- $\beta$ cells are distinct and demonstrate advantages of investigating SIX2-dependent gene expression in primary adult $\beta$ cells.

\section{Identifying direct genetic targets of SIX2 regulation in human $\beta$ cells}

To identify direct genetic targets of SIX2 in primary human islet cells, we performed cleavage under targets and release using nuclease (CUT\&RUN) (Skene and Henikoff 2017; Hainer et al. 2019), which enables the sensitive detection of genomic loci bound by TFs (Fig. 4A; Materials and Methods). Because antibodies that detected native islet SIX2 for CUT\&RUN were not available, we misexpressed in pseudoislets a transgene encoding human SIX2 tagged with the FLAG immuno-epitope (SIX2FLAG) from a rat insulin promoter element (RIP) (Karlsson et al. 1987), then sequenced DNA bound by the SIX2-FLAG protein with an anti-FLAG antibody (Supplemental Fig. S4A). Thus, interpretation of CUT\&RUN here is qualified by the possibility that SIX2-FLAG may bind sites not bound by native SIX2. We used the HOMER algorithm (Heinz et al. 2010) to identify genomic regions that were bound by SIX2-FLAG in samples from three islet donors $(P \leq 0.01$ compared with IgG controls). Heat map visualization of independent peaks (Fig. 4B) as well as histogram plotting of averaged reads (Supplemental Fig. S4B) showed enrichment of read densities in the peak centers for the SIX2-FLAG libraries, whereas IgG controls showed minimal enrichment at these sites (Fig. 4B; Supplemental Fig. S4B). As further validation of the specificity of CUT\&RUN, we found that SIX2-FLAG-bound genomic peaks were significantly enriched for the SIX2 DNA-binding motif, as well as the SIX1 DNA-binding motif, and motifs of other $\beta$-cell-enriched TFs, like MAFB (Fig. 4C). We used the GREAT algorithm (McLean et al. 2010) to associate SIX2-FLAG-bound genomic regions to 10,270 genes (Fig. 4D). Inadequate yields precluded analogous SIX3FLAG studies (Materials and Methods).

To nominate candidate genes that might be directly regulated by SIX2, we then identified genes that (1) neighbored SIX2-FLAG binding sites and (2) had differential expression after $S I X 2^{\mathrm{kd}}$. After intersection of CUT\&RUN with 2170 DE genes after $S I X 2^{\mathrm{kd}}$, we identified $1186^{\text {" }}$ overlapping genes" (Fig. 4D; Supplemental Table S4). Sixty- 
A

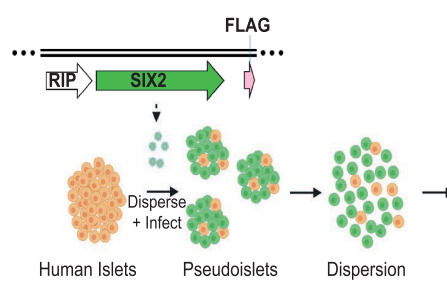

D

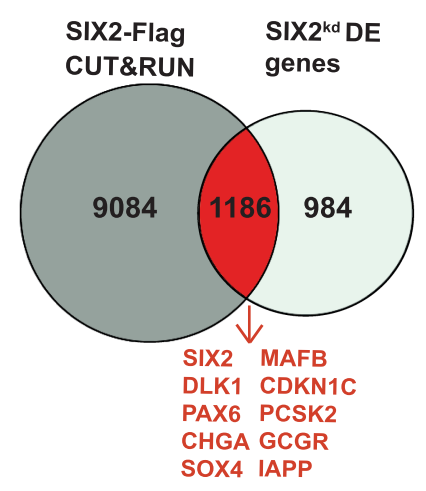

B

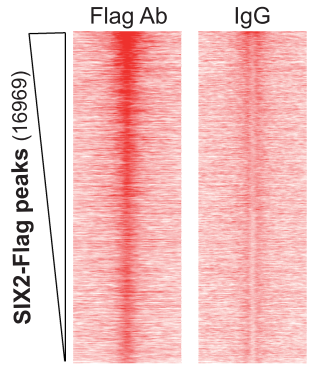

C
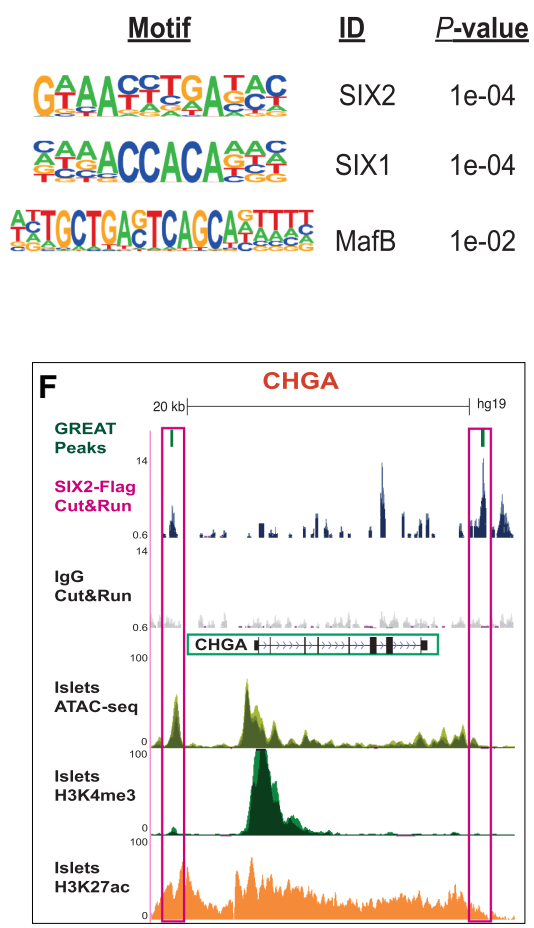

Figure 4. Identification of presumptive SIX2 genetic targets in primary human $\beta$ cells using CUT\&RUN. $(A)$ Schematic of the CUT\&RUN approach: Pseudoislets overexpressing SIX2-FLAG under the RIP promoter were used for CUT\&RUN with anti-FLAG antibody ( $n=3$ independent donors). (B) Heat map showing enrichment of peak read densities at the center of the peak for the CUT\&RUN libraries generated with FLAG antibody, but not for IgG. Peaks were called using HOMER. $(C)$ Enriched motifs in the differential peaks were identified by HOMER. $(D)$ Overlap of the SIX2-associated genomic regions and the SIX2 ${ }^{\mathrm{kd}}$ DE genes. $(E, F)$ Tracks showing SIX2FLAG genomic regions associated with GCGR $(E)$ or CHGA $(F)$. Accessible chromatin regions in human islets are shown by ATACseq, H3K4me3, and H3K27ac ChiP-seq tracks. SIX2-FLAG CUT\&RUN peaks are shown in pink boxes (note: for GCGR, two peaks are shown), and regulated genes are highlighted in green boxes.

four percent of these genes (754/1186) had reduced mRNA levels after $S I X 2^{\mathrm{kd}}$, consistent with a role for SIX2 in activating $\beta$-cell gene expression. Presumptive direct SIX 2 targets identified by this approach included $P A X 6, I A P P$, $M A F B, C D K N 1 C, D L K 1, P C S K 2, G C G R, M L X I P L$, and CHGA. As expected, SIX2-FLAG-bound genomic regions in presumptive SIX2 target genes were found in accessible chromatin and colocalized with activation-associated H3K4me3 and H3K27ac histone marks identified by prior islet ATAC-seq and ChIP-seq studies (Mularoni et al. 2017). This alignment further supports the conclusion that SIX2 binds active genomic regulatory elements governing hallmark $\beta$-cell genes (Fig. 4E,F; Supplemental Fig. S4C-E; Supplemental Table S4). Thus, our targeted nuclease-based analysis revealed hundreds of SIX2-associated candidate regulatory elements, including many that likely regulate expression of hallmark $\beta$-cell factors.

\section{SIX3 and SIX2 regulate distinct gene sets in adult human $\beta$ cells}

Gain-of-function studies have linked SIX3 to adult human $\beta$-cell functional maturation (Arda et al. 2016). To identify genes whose expression is regulated by SIX3 in human $\beta$ cells, we used flow cytometry to purify $\beta$ cells from human pseudoislets after SIX3 ${ }^{\mathrm{kd}}$ (Supplemental Fig. S5A-C; Materials and Methods). Like in our SIX $2^{\mathrm{kd}}$ studies, we confirmed enrichment of $\mathrm{INS}^{+} \mathrm{GFP}^{+} \beta$ cells-and depletion of non- $\beta$ cells-with qRT-PCR analysis (Supplemental Fig. S5D), then generated, sequenced, and analyzed RNA-seq libraries $(n=3$ independent donors). We achieved $50 \%$ reduction of SIX3 mRNA in purified INS ${ }^{+}$ GFP $^{+} \beta$ cells (Fig. 5A; Supplemental Fig. S5E). In contrast, SIX2 mRNA levels were not detectably changed (Fig. 5A). As expected, analysis of RNA-seq libraries with Pearson correlation analysis and hierarchical clustering revealed close clustering of $S I X 3^{\mathrm{kd}}$ and control $\beta$-cell samples from the same donor (Fig. 5B; Supplemental Fig. S5F). With the DE-Seq2 algorithm (Materials and Methods), we identified 263 genes with significantly decreased mRNA levels $(P<0.05)$ (Supplemental Table S5), including SIX3 itself (Fig. 5A), and 372 genes with significantly increased mRNA levels in SIX3 ${ }^{\mathrm{kd}} \beta$ cells $(P<0.05)$ (Fig. 5E; Supplemental Table S6). Thus, the number of DE genes with increased mRNA outnumbered those with decreased mRNA after $S I X 3^{\mathrm{kd}}$, unlike DE genes after $S I X 2^{\mathrm{kd}}$. Gene ontology (GO) analysis suggested molecular functions of the enriched gene sets, including regulation of 
Bevacqua et al.

A

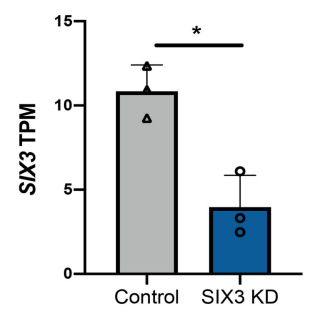

C

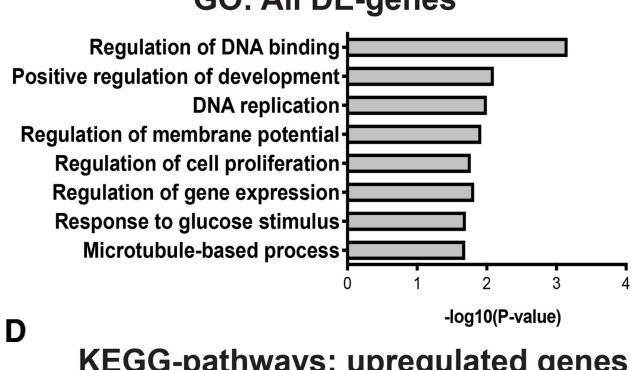

KEGG-pathways: upregulated genes
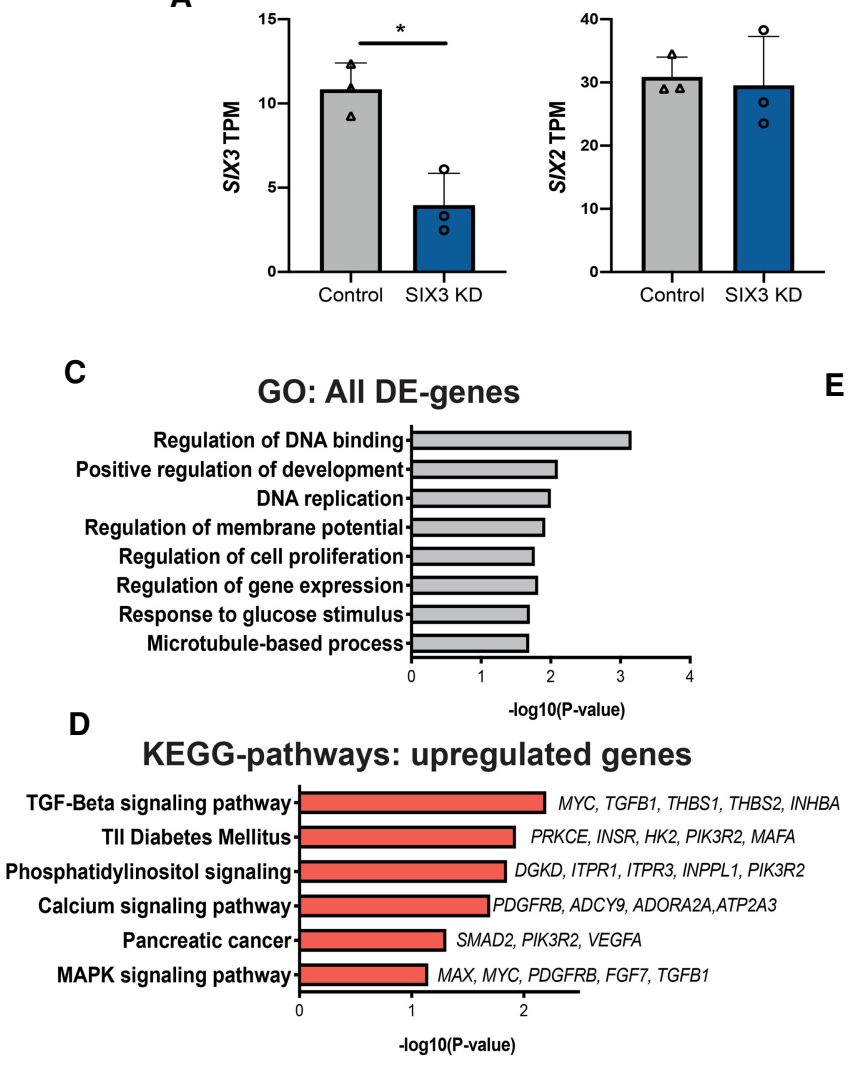

E
B
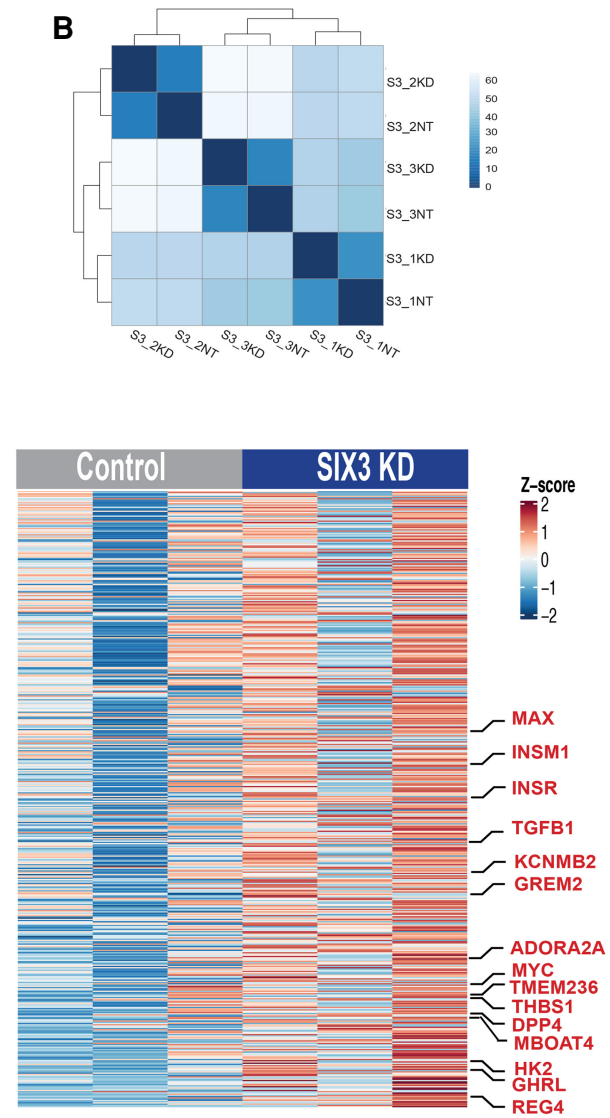

G

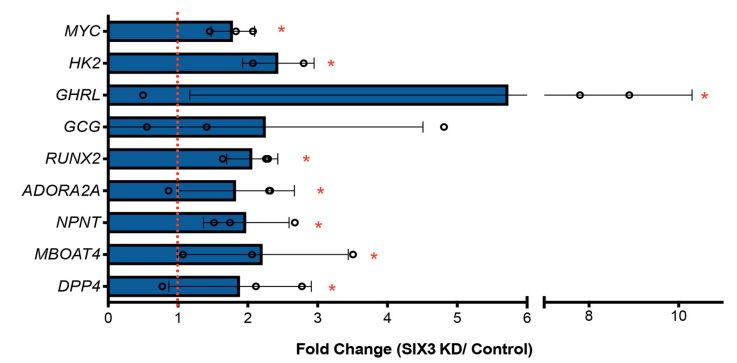

Figure 5. RNA-seq of $S I X 3^{\mathrm{kd}} \beta$ cells reveals a distinct gene set regulated by SIX3. (A) Normalized transcript levels of SIX3 and SIX2 in GFP-expressing $\beta$ cells. (Gray bar) Control, (blue bar) $S I X 3^{\mathrm{kd}} . n=3$. (B) Heat map of the sample-to-sample distances for all the samples used in this experiment. $(C)$ GO term enrichment in genes deregulated in $\beta$ cells post-SIX $3^{\mathrm{kd}}$. (D) KEGG pathways enriched in genes up-regulated in $\beta$ cells post-SIX $3^{\mathrm{kd}}(n=3)$. (E) Heat map showing all up-regulated genes upon $S I X 3^{\mathrm{kd}}$ in $\beta$ cells. $(F)$ Overlapped DE genes in adult $\beta$ cells post $S I X 2^{\mathrm{kd}}$ and $S I X 3^{\mathrm{kd}}$. (G) Fold transcript levels of non- $\beta$-cell genes significantly altered in $\beta$ cells post-SIX3 ${ }^{\mathrm{kd}}(n=3)$. The data are presented as mean; error bars represent the standard error. $\left(^{*}\right) P<0.05$.

DNA binding, response to glucose stimulus, and DNA replication (Fig. 5C; Supplemental Fig. S5G). Up-regulated $\mathrm{DE}$ genes associated with the latter term included established regulators of $\beta$-cell replication, like $M Y C, M A X$, and INSM1 (Fig. 5C,E). Pathway analysis of the DE up-regulated genes (Materials and Methods) included TGF- $\beta$ signaling, type 2 diabetes mellitus, and calcium signaling pathway (Fig. 5D).

The DE genes after $S I X 3^{\mathrm{kd}}$ were largely distinct from DE genes after SIX $2^{\mathrm{kd}}$; only $133 / 2805 \mathrm{DE}$ genes $(<5 \%)$ overlapped between $S I X 2^{\mathrm{kd}}$ and $S I X 3^{\mathrm{kd}}($ Fig. $5 \mathrm{~F}$; Supplemental
Table S8; Supplemental Fig. S6A,B). Moreover, among these $133 \mathrm{DE}$ genes, $112 / 133(84 \%)$ changed in the opposite direction after $S I X 2^{\mathrm{kd}}$ compared with $S I X 3^{\mathrm{kd}}$, such as KCNMB2, GREM2, OLIG1, and TLE2. After SIX3 ${ }^{\mathrm{kd}}$ there was also a significant increase of mRNAs encoding genes not usually expressed in adult human $\beta$ cells. This included genes encoding factors enriched or exclusively expressed in islet a cells or $\varepsilon$ cells, like DPP4, NPNT, TMEM236, ADORA2A, and GHRL, which encodes the $\varepsilon$-cell hormone ghrelin, and MBOAT4 (which encodes an acetyl-transferase for ghrelin) (Fig. 5E,G). While not 
reaching statistical significance, we also detected an average 2.5 -fold increase of mRNA encoding GCG in $S I X 3^{\mathrm{kd}} \beta$ cells (Fig. 5G). In $S I X 3^{\mathrm{kd}} \beta$ cells, we also identified increased average levels of 70 mRNAs that are typically expressed highly in fetal $\beta$ cells, but attenuated or extinguished in adult $\beta$ cells (Fig. 6A,B; Supplemental Table S9; Blodgett et al. 2015; Arda et al. 2016). This latter group of genes included MYC (Puri et al. 2018) and a "disallowed" gene (Pullen et al. 2010) that encodes hexokinase (HK2) (for review, see Lemaire et al. 2016). Moreover, none of these mRNAs increased in $\beta$ cells after SIX $2^{\mathrm{kd}}$. Together, our findings support the view that SIX2 and SIX3 regulate distinct gene sets in human $\beta$ cells.

We previously showed that SIX3 expression in pseudoislets from juvenile human donors aged $0.5-2$ yr (which lack SIX3 expression) was sufficient to stimulate insulin secretion in vitro (Arda et al. 2016); however, transcriptome studies were not performed. To assess changes of gene expression stimulated by SIX3, we misexpressed a SIX3-FLAG transgene in pseudoislets from two juvenile donors (ages 1.5 and 3 yr) (Fig. 6C; Supplemental Table S1). Flow cytometry and western blotting verified and quantified expression of transgenic SIX3-FLAG (Supplemental Fig. S7A-C). qRT-PCR analysis of purified $\beta$ cells showed a reduction in GCG levels and an average increase of INS mRNA levels following SIX3 misexpression (Fig. 6D), as previously reported (Arda et al. 2016). RNA-seq of purified SIX3-FLAG ${ }^{+}$INS $^{+} \beta$ cells (Materials and Methods) confirmed reduced mRNAs encoding GCG, HK2, MYC, TMEM236, MBOAT4, RUNX2, GREM2, and NPNT, mRNAs found increased after SIX $3^{\mathrm{kd}}$ in primary $\beta$ cells (Supplemental Fig. S7D; Supplemental Table S10). Thus, SIX3 gain- and loss-of-function studies here produced reciprocal changes in expression of multiple genes, supporting the view that SIX3 suppresses adult $\beta$ cell expression of gene sets expressed abundantly in fetal or neonatal $\beta$ cells, or in adult $\alpha$ and $\varepsilon$ cells. We conclude that SIX3 reinforces mature $\beta$-cell function, in part, by suppressing fetal gene expression programs and alternative islet cell fates (Fig. 6E).

\section{A Juvenile $\beta$ cell Adult $\beta$ cell SIX $3^{\mathrm{kd}}$ enriched genes upregulated genes}

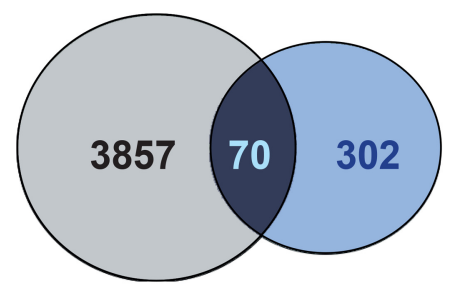

B

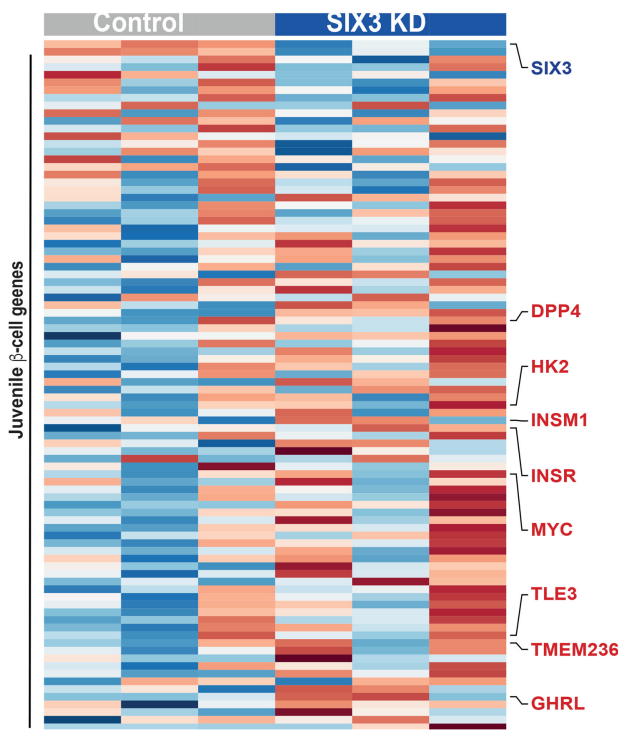

\section{Juvenile Primary} Human Islets

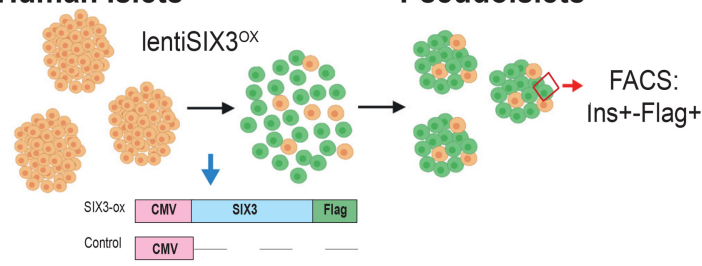

D
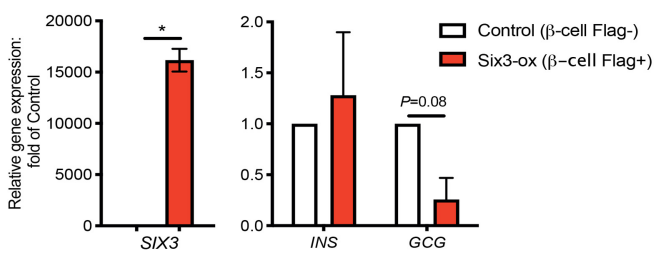

E

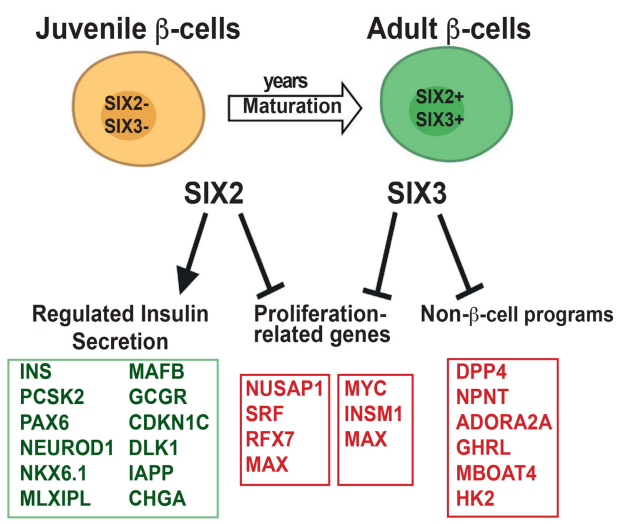

Figure 6. SIX3 represses non- $\beta$-cell programs in the adult $\beta$-cell. (A) Venn diagram showing juvenile $\beta$-cell genes up-regulated post-SIX3 ${ }^{\mathrm{kd}}$ in adult $\beta$ cells. $(B)$ Heat map of adult down-regulated and juvenile up-regulated genes in adult $\beta$ cells post-SIX $3^{\mathrm{kd}}$. $(C)$ Schematic detailing the juvenile pseudoislet technique used to overexpress SIX3-FLAG (SIX3-ox) in juvenile pseudoislets $(n=2)$ and of the constructs used to overexpress SIX3 in juvenile pseudoislets: FACS was used to sort FLAG+ $\beta$ cells. (D) SIX3, INS, and GCG mRNA expression in FLAG+-expressing $\beta$ cells post FACS. (White bar) Control, (red bar) SIX3-ox. $n=2$. (E) Schematics showing proposed coordinated regulation of maturation by SIX2 and SIX3 in the $\beta$-cell. The data are presented as mean; error bars represent the standard error. $\left.{ }^{*}\right) P<0.05$. 
Human $\beta$-cell expression of SIX2 is reduced in islets from T2D donors

It remains unknown whether the expression of SIX2 or SIX3 changes in islet $\beta$ cells obtained from T2D patients. We found that both SIX2 and SIX3 mRNA appeared to be reduced in purified whole islets from subjects with established T2D $(n=4)$, compared with islets from nondiabetic controls $(n=7)$ (Fig. 7A; for donor information, see Supplemental Table S1). In contrast, expression of GPD2 and LEPROTL2, previously found up-regulated in prior studies (Segerstolpe et al. 2016), was unaltered in T2D islets (Fig. 7A).

Bulk RNA-seq from FACS-purified $\alpha$ and $\beta$ cells was used to assess SIX2 and SIX3 expression in $\beta$ cells (Fig. 7B-D; see the Materials and Methods). Transcriptome analysis confirmed significant reduction of SIX2 mRNA in purified $\beta$ cells from T2D islets compared with $\beta$ cells from control islets $(P \leq 0.01)$ (Fig. 7B-C; Supplemental Table S11), while SIX3 mRNA levels were not significantly changed (Fig. 7D). Thus, SIX2 expression was reduced in $\beta$ cells in islets from cadaveric T2D donors. Moreover, $\beta$ cell regulation of SIX2 and SIX3 in these T2D islets was uncoupled. We also detected little to no expression of SIX2 and SIX3 in purified a cells from control or T2D islets (Fig. 7C,D). In addition to reduced SIX2 expression in $\beta$ cells, we also noted impaired expression of $S I X 2$ target genes, including $M A F B$, GREM1, GCGR, and CDKN1C, a candidate T2D risk gene (Fig. 7B,E-G; Supplemental Table S11). Consistent with our studies of impaired insulin secretion after $S I X 2^{\mathrm{kd}}$ (Fig. 1G), glucose-stimulated insulin secretion studies revealed impaired insulin secretion by islets from subjects with T2D compared with nondiabetic controls (Fig. 7H,I; see the Materials and Methods).
A
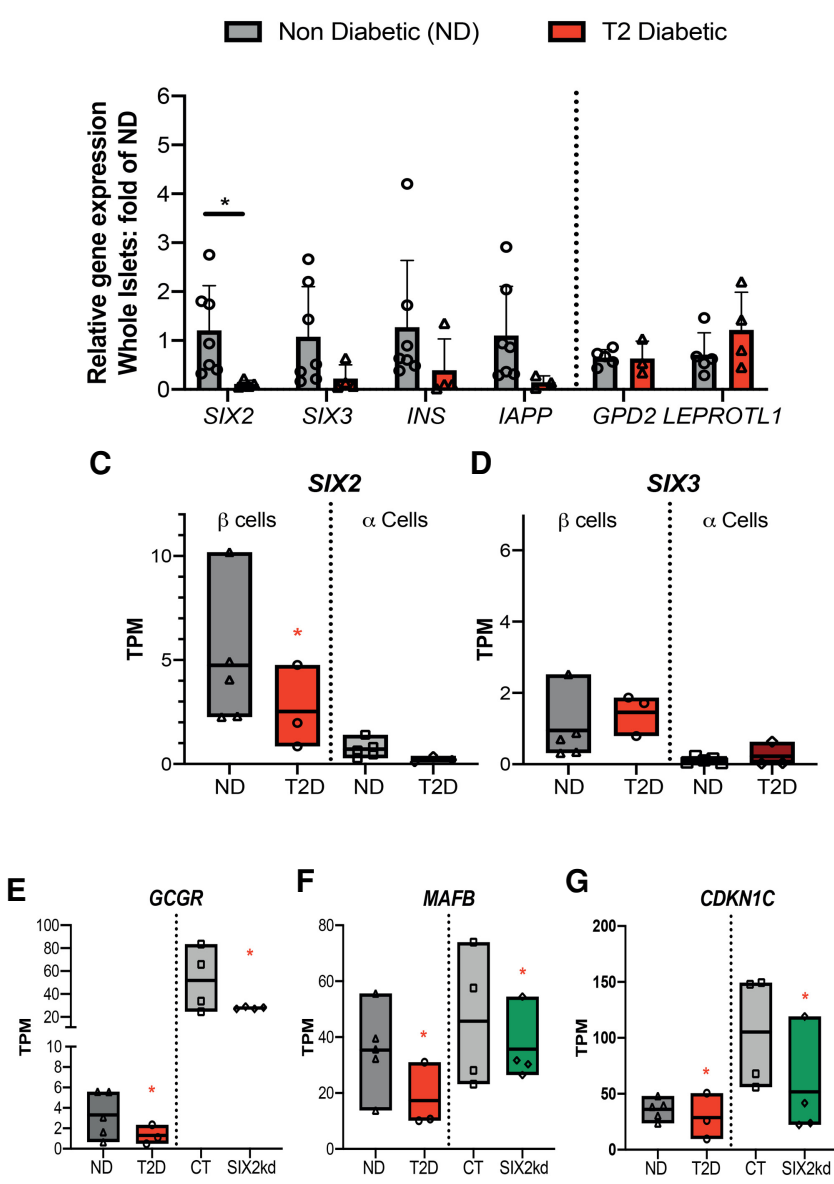
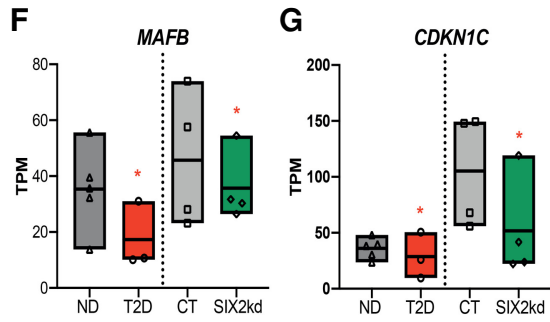

B

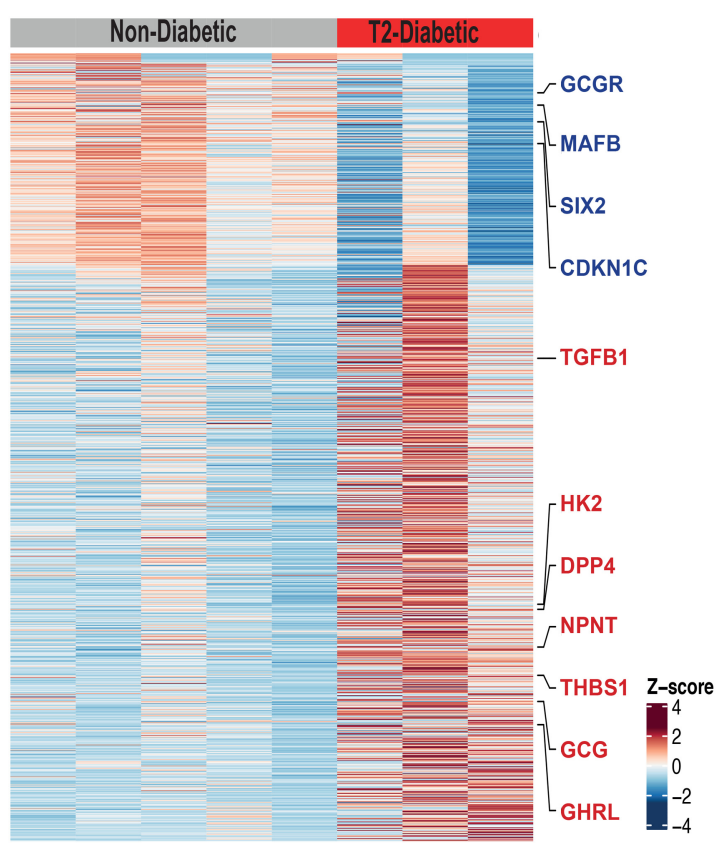

$\mathbf{H}$

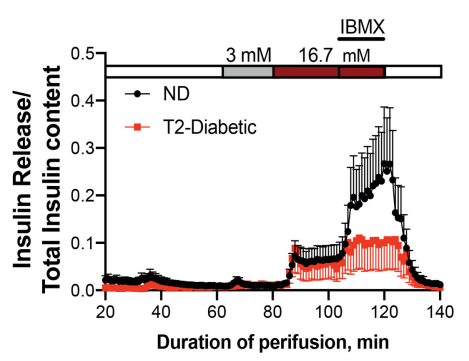

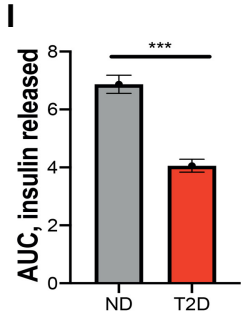

Figure 7. SIX2 expression is reduced in $\beta$ cells from T2D donors. $(A)$ Gene expression levels in whole islets from nondiabetic (ND; gray bars) $(n=5)$ or type 2 diabetic (T2D; red bar) $(n=3)$. $(B)$ Heat map showing DE genes in nondiabetic versus T2 diabetic $\beta$ cells. $(C, D)$ Box plots displaying TPM counts of $S I X 2(C)$ and $S I X 3(D)$ in nondiabetic (ND) $(n=5) \beta$ cells (dark-gray bars) and $\alpha$ cells (light-gray bars) or type 2 diabetic (T2D) $\beta$ cells (red bars) and a cells (dark-red bars) $(n=3)$. (E-G) Box plots displaying TPM GCGR $(E), M A F B(F)$, and $C D K N 1 C$ $(G)$ in $\beta$-cells of $\mathrm{ND}(n=5)$ and T2D $(n=3)$, the expression of which is DE in adult $\beta$ cells post-SIX2 ${ }^{\mathrm{kd}}$. (Gray bars) Çontrol, (green bars) SIX $2^{\mathrm{kd}}$. $(H)$ Insulin secretion of ND $(n=5)$ versus T2D $(n=3$; see the Materials and Methods). (I) Plot of the total area under the curve of the released insulin. The data in $A$ are presented as mean; error bars represent the standard error. Box plots show the mean. (Red *) $P \leq 0.01,\left(\right.$ black $\left.^{*}\right) P<0.05$. 
Although SIX3 mRNA levels were not detectably changed in our sampling of T2D $\beta$ cells, a subset of SIX3 targets was differentially expressed in T2D $\beta$ cells, including DPP4, NPNT, and GHRL; TGF- $\beta$ signaling factors encoded by TGFB1 and THBS1; and the disallowed gene HK2 (Fig. 7B). This raises the possibility that factors collaborating with SIX3 to regulate these genes might be changed in T2D $\beta$ cells.

Together, these findings suggest that dysregulation of SIX2- and SIX3-dependent genetic programs could contribute to impaired islet $\beta$-cell fate and function in T2D. These findings also support prior genome-wide association studies linking the locus encoding SIX2 and SIX3 to risk for T2D and diabetes-related traits (Kim et al. 2011; Hachiya et al. 2017; Varshney et al. 2017; Spracklen et al. 2018, 2020), raising the possibility that genetic influences might additionally modulate $\beta$-cell expression of SIX2 or SIX3.

\section{Discussion}

Here, we overcame inherent challenges facing postnatal human developmental studies to investigate the roles of SIX 2 and SIX 3 in human pancreatic $\beta$-cell maturation. Using genetic approaches, we show that SIX2 is required for expression of multiple hallmark genes in human $\beta$ cells. In addition to regulation of genes governing $\beta$-cell function, we show that SIX3-unlike SIX2-suppresses expression of genes typically expressed in a cells or other non- $\beta$ cells. Thus, our studies provide index evidence that SIX2 and SIX3 regulate distinct sets of genetic targets in adult human $\beta$ cells. shRNA-mediated suppression of either SIX2 or SIX3 expression in primary human islets impaired regulated insulin secretion by $\beta$ cells. Supporting these findings, we found evidence of reduced expression of SIX2 and downstream targets in islet $\beta$ cells from human subjects with T2D, which coincided with significantly reduced insulin secretion by these islets. In sum, our study unveils a requirement for SIX2 and SIX3 in establishing and maintaining adult human $\beta$-cell function and fate (Fig. 6E).

Prior to our study, it was unclear what roles SIX2 and SIX3 had in adult human $\beta$-cell function. SIX2 and SIX3 are coexpressed in adult human $\beta$ cells, and developmental studies of human islet cells have revealed coincident increases of SIX2 and SIX3 expression after the first decade of life (Arda et al. 2016, 2018; Blodgett et al. 2015). Moreover, studies of putative SIX2 and SIX3 cis-regulatory elements in humans and other systems have suggested these genes may be coregulated (Spracklen et al. 2018; Suh et al. 2010). A common set of SIX2 and SIX3 targets identified here includes regulators of cell cycle progression. However, the onset of SIX2 and SIX3 in human $\beta$ cells occurs well after the period of neonatal expansion (Blodgett et al. 2015; Arda et al. 2016), suggesting that the post-mitotic state of $\beta$ cells is established by other factors, and then reinforced by SIX2 and SIX3. Consistent with this possibility, we observed that reduction of SIX2 alone or SIX3 alone did not increase markers of $\beta$-cell S-phase like MKI67 (Supplemental Tables S2-S5). Moreover, we showed in our prior work that misexpression of either SIX2 or SIX3 was sufficient to suppress proliferation of the human $\beta$-cell line EndoC $\beta \mathrm{H} 1$ (Arda et al. 2016). Enforcement of the post-mitotic state in $\beta$ cells has been linked to attainment of mature function (Helman et al. 2016; Puri et al. 2018; Mandelbaum et al. 2019).

The majority of differentially expressed genes after $S I X 2^{\mathrm{kd}}$ showed reduced expression, including those encoding crucial human $\beta$-cell factors like insulin and glucokinase, and essential TFs that coordinate pancreatic islet development and $\beta$-cell function in humans. Consistent with this, we observed reduced insulin secretion after $S I X 2^{\mathrm{kd}}$. In contrast, after SIX $3^{\mathrm{kd}}$ the majority of DE genes showed increased expression. These included transcripts encoding factors not normally expressed in healthy $\beta$ cells, like the $\varepsilon$-cell hormone ghrelin, the a-cell-enriched protease DPP4, and the disallowed factor HK2 (Dhawan et al. 2015). These $S I X 3^{\mathrm{kd}}$ findings are consistent with previous studies suggesting that SIX3 can function as a transcriptional repressor (Kobayashi et al. 2001). Thus, our lossof-function studies revealed SIX2- and SIX3-dependent mechanisms that regulate native maturation and fate of human $\beta$ cells. Here, the degree of SIX 2 mRNA reduction after $S I X 2^{\mathrm{kd}}$ was greater than the degree of SIX3 mRNA loss after $S I X 3^{\mathrm{kd}}$; thus, future studies that achieve more complete SIX2 or SIX3 loss of function could identify additional $\beta$-cell genetic targets. Our study was also limited by the inherent variability of cadaveric human islet donors, as we and others have previously reported (Arda et al. 2016; Segerstolpe et al. 2016; Enge et al. 2017; Peiris et al. 2018). While SIX3 expression is restricted to the $\beta$ cell, SIX2 is also expressed in islet $\delta$ cells (Baron et al. 2016; Muraro et al. 2016). Thus, changes observed after SIX $2^{\mathrm{kd}}$ could reflect both $\beta$-cell autonomous and nonautonomous mechanisms. Studies here also revealed that SIX2 and SIX3 expression in $\beta$ cells can be genetically uncoupled and correspond well with our data showing that SIX 2 and SIX 3 regulate distinct $\beta$-cell gene sets. Thus, distinct mechanisms likely govern expression and activity of SIX2 and SIX 3 in $\beta$ cells from healthy and diabetic cadaveric donors.

Elucidating how SIX2 and SIX3 expression are regulated should be aided by our identification of their targets in human $\beta$ cells. Prior studies have shown that transcription factors like SIX2 and SIX3 expressed in human $\beta$ cells show increased expression with age (Aguayo-Mazzucato et al. 2011; Blodgett et al. 2015; Arda et al. 2016; Wang et al. 2016b). For shRNA-based studies here we used islets from donors $>22 \mathrm{yr}$ of age, when adult levels of SIX2 and SIX3 have been established. Intense interest in SIX2 and SIX3 regulation also stems from association of the locus encoding these factors to T2D and related traits like fasting hyperglycemia (Kim et al. 2011; Hachiya et al. 2017; Varshney et al. 2017; Spracklen et al. 2018, 2020). However, studies of whole islet RNA, or prior single islet cell RNA-seq investigations by us and others (Segerstolpe et al. 2016; Camunas-Soler et al. 2020) were not sufficiently sensitive to detect changes of SIX2 or SIX3 mRNA in $\beta$ cells isolated from donors with T2D. Studies here provide 
index evidence that (1) expression of SIX2, and a subset of SIX2-dependent genes like GCGR, are significantly reduced in $\beta$ cells from T2D donors, and (2) islets from T2D donors with reduced $\beta$-cell expression of SIX2 had impaired insulin secretion (Fig. 7). While we did not detect changes in SIX3 expression in T2D islets here, additional studies are required to exclude the possibility that $\beta$-cell SIX3 dysregulation is a feature of T2D.

A recent report described phenotypes after SIX2 loss in hPSC-derived $\beta$-like cells (SC- $\beta$ cells) (Velazco-Cruz et al. $2020)$. While $25 \%$ of these insulin ${ }^{+}$SC- $\beta$ cells express SIX2 mRNA, they lack other markers of mature $\beta$ cells like MAFB or SIX3, thus precluding studies of SIX3 loss of function. After shRNA-mediated suppression of $S I X 2$, Velazco-Cruz et al. (2020) reported reduced insulin protein content, loss of glucose-stimulated insulin secretion without effects on "basal" insulin secretion at low glucose concentration ( $2 \mathrm{mM}$ ), and significant changes in expression of $>10,000$ genes, assessed by RNA-seq of unsorted hESC progeny, with enrichment of gene sets related to insulin secretion and calcium signaling. This included significant increases of multiple transcripts encoding islet a cell or $\delta$ cell products, like SST, DPP4, MBOAT4, and FSTL1 (Velazco-Cruz et al. 2020). These findings support the conclusion that SIX2 is required for SC- $\beta$ cells derived from hESCs to acquire some features of native human $\beta$ cells.

In our study, we assessed the effects of SIX2 or SIX3 loss in native human $\beta$ cells. After $S I X 2^{\mathrm{kd}}$, we observed reduction of both basal and glucose-stimulated insulin secretion, without reduction of islet insulin content. FACS purification of Insulin ${ }^{+} \beta$ cells (and elimination of SIX2 ${ }^{+}$ $\delta$ cells) and RNA-seq revealed significant changes in mRNA levels of 2100 genes, with gene set analysis revealing enrichment of terms related to proliferation, insulin secretion, calcium signaling, carbohydrate metabolism, and exocytosis. While some of these gene sets overlapped with those in SC- $\beta$ cells (Velazco-Cruz et al. 2020), there was an overall lack of concordance between gene sets (Supplemental Fig. S3; Supplemental Table S12). For example, after SIX $2^{\mathrm{kd}}$ we observed reduced mRNA encoding the calcium channel subunits CACNA1A and CACNA1D ("calcium signaling"), incretin receptors GIPR and GCGR ("insulin secretion"), and transcription factors with established roles in native $\beta$-cell regulation like MAFB, NEUROD1, NKX6.1, and TCF7L2; these changes were not noted in SC- $\beta$ cells. Moreover, we did not observe increased expression of non- $\beta$-cell markers like DPP4, MBOAT4, and FSTL1 after SIX $2^{\mathrm{kd}}$. Instead, we observed increased expression of these genes, and other non- $\beta$-cell or disallowed genes after SIX $3^{\mathrm{kd}}$. These contrasts raise the possibility that SIX2 activity in SC- $\beta$ cells includes ectopic functions normally fulfilled by SIX3 or other factors. Together, our findings clarify the importance of investigating SIX2 and SIX3 functions in bona fide adult $\beta$ cells. While models of human $\beta$-cell development, like stem cell-derived insulin ${ }^{+}$cells and immortalized $\beta$-cell lines have value (Sneddon et al. 2018), to date they remain fundamentally different from genuine pancreatic islet cells in gene regulation, function, proliferation, and cellular com- position. Our studies further suggest that simultaneous expression of both SIX2 and SIX3 may be required to produce consummately functional replacement $\beta$ cells from renewable sources, like human stem cell lines.

In summary, this study unveils SIX 2 and SIX 3 functions crucial for postnatal human islet and $\beta$-cell development and maturation and reveals how $\beta$-cell dysfunction might develop in diabetes. Our work demonstrates that SIX2 and SIX3 coordinately govern distinct genetic programs that increase insulin production and enhance mature $\beta$-cell physiological functions, enforce $\beta$-cell fate by suppressing alternative genetic programs, and suppress proliferation. Findings here also provide a unique developmental "roadmap" for achieving human $\beta$-cell replacement.

\section{Materials and methods \\ Human islet procurement}

Deidentified human islets were obtained from healthy, nondiabetic organ donors or type 2 diabetic donors procured through the Integrated Islet Distribution Network (IIDP), National Diabetes Research Institute (NDRI), International Institute for the Advancement of Medicine (IIAM), and the Alberta Diabetes Institute Islet Core. For T2D studies, data from the Human Pancreas Analysis Program (HPAP-RRID: SCR_016202) Database (https://hpap .pmacs.upenn.edu), a Human Islet Research Network (RRID: SCR_014393) consortium (UC4-DK-112217 and UC4-DK112232) was used. See Supplemental Table S1 for details.

\section{Constructs and lentivirus production}

Lentiviral constructs coding for shRNAs targeting human SIX3 or SIX2 were obtained from Dharmacon. plenti-CMV-SIX3-cMycDDK was used in juvenile islet experiments (Origine). plentiRIP-SIX2-cMyc-DDK was generated by replacing the CMV promoter of plenti-CMV-SIX2-cMyc-DDK (Origine) with the rat insulin promoter (RIP). Lentiviruses were produced by transfection of HEK293T cells with lentiviral constructs, pMD2.G (Addgene 12259) and psPAX2 (Addgene 12260) packaging constructs. Supernatants were collected and concentrated by PEG-it (System Biosciences).

\section{Human pseudoislet generation and transduction}

Human islets were dispersed into single cells by enzymatic digestion (Accumax, Invitrogen) and transduced with $1 \times 10^{9}$ viral units $/ 1 \mathrm{~mL}$ lentivirus. Transduced islet cells were cultured in ultra-low attachment well plates for $5 \mathrm{~d}$ prior to further analysis.

\section{RNA extraction and quantitative RT-PCR}

RNA was isolated from whole pseudoislets using the PicoPure RNA isolation kit (Life Technologies). For sorted $\beta$ and $\alpha$ cells, RNA was isolated using the RecoverALL isolation kit (Invitrogen by Thermo Fisher Scientific). cDNA was synthesized using the Maxima first strand cDNA synthesis kit (Thermo Scientific), and gene expression was assessed by PCR using TaqMan gene expression mix (Thermo Scientific) and the following probes ACTIN-B, Hs4352667_m1; SIX2, Hs00232731_m1; SIX3, Hs00193 667_m1; insulin, Hs00355773_ml; glucagon, Hs00174967_m1; CPA-1, Hs00156992_m1; and KRT19, Hs01051611_gH. 
In vitro insulin secretion assays

Batches of 25 pseudoislets were used for in vitro secretion assays as previously described (Peiris et al. 2018). Briefly, pseudoislets were incubated at $2.8,5.6,16.7,25$, and $25 \mathrm{mM}+$ IBMX glucose concentrations for $60 \mathrm{~min}$ each, and supernatants were collected. Secreted human insulin in the supernatants and pseudoislet lysates were quantified using a human insulin ELISA kit (Mercodia). Secreted insulin levels are presented as a percentage of total insulin content. Perifusion data of T2 diabetic versus nondiabetic samples were acquired from the Human Pancreas Analysis Program (HPAP-RRID: SCR_016202).

\section{Immunohistochemistry}

Human pseudoislets were fixed for $1 \mathrm{~h}$ at $4^{\circ} \mathrm{C}$ and embedded in collagen (Wako Chemicals) and OCT before sectioning and staining as previously described (Arda et al. 2016). Primary antibodies used were guinea pig anti-Insulin (1:1000; DAKO A0564), mouse anti-glucagon (1:500; Sigma), and mouse anti-SST (1:500). Secondary antibodies were incubated for $2 \mathrm{~h}$ at room temperature. Images were obtained using a Leica SP2 confocal microscope.

\section{Intracellular staining and FACS sorting of human islet cells}

Detailed protocol can be found in Peiris et al. (2018). Briefly, pseudoislets were dispersed into single cells and stained with LIVE/ DEAD Fixable Near-IR dead cell stain kit (Life Technologies) prior to fixation with $4 \%$ paraformaldehyde. After permeabilization, cells were stained with the following antibodies: guinea pig antiinsulin (1:100; Dako) followed by anti-guinea pig Alexa Fluor 555 (1:100; Sigma) and mouse anti-glucagon antibody Alexa Fluor 647 (1:100; Santa Cruz Biotechnology). Juvenile islet cells from SIX3FLAG pseudoislets were stained with anti-FLAG antibody-555 (1:100; Biolegend). Labeled cells were sorted on a special order five-laser FACS Aria II (BD Biosciences) using a 100- $\mu \mathrm{m}$ nozzle, with appropriate compensation controls and doublet removal. Sorted cells were collected into low retention tubes containing $50 \mu \mathrm{L}$ of FACS buffer.

\section{$R N A$ isolation and preparation of RNA-seq libraries}

A total of 20,000 sorted, fixed $\beta$ cells were used for each RNA-seq library construction of RNA with RIN number $>7$. SMART-seq v4 Ultra Low input RNA kit (Clontech) was used to amplify cDNA, which was subsequently sheared, resulting in 200- to 500-bp fragments. RNA-seq libraries were generated using the Low Input library preparation kit v2 (Clontech). Barcoded libraries were then multiplexed and sequenced as paired-end 150-bp reads on the Illumina HiSeq4000 platform. A total of eight libraries were generated from four different donors used for the $S I X 2^{\mathrm{kd}}$ (four libraries) and the respective control $\beta$ cells (four libraries), while six libraries were generated from three different donor $\beta$ cells used for $S I X 3^{\mathrm{kd}}$ and their respective controls.

\section{Bioinformatic and statistical analysis}

RNA-seq analysis was performed on SIX $2^{\mathrm{kd}}$ and control $\beta$-cell libraries from four donors and on SIX $3^{\mathrm{kd}}$ and $\operatorname{con}$ trol $\beta$-cell libraries from three donors. FastQC v0.11.4 was used for quality control. All libraries had $>75$ million reads, and barcodes were trimmed using Trimgalore_0.5.0. Reads were aligned to the human genome index (hg19) using STAR v2.6.1d (Dobin et al. 2013). Transcripts per million (TPM) were quantified using RSEM v1.3.0 (Li and Dewey 2011). Differentially expressed genes with fold change were detected using the DESeq2 R package (Love et al. 2014) for the two experimental conditions. The Database for Annotation, Visualization, and Integrated Discovery (DAVID) v6.7 was used (Huang et al. 2009) for gene set enrichment analysis. RNA-seq data sets of genes enriched in adult $\beta$ cells versus juvenile $\beta$ cells were obtained from Arda et al. (2016) (GEO: GSE79469) and Blodgett et al. (2015) (GEO: GSE67543). The probability of finding $x$ overlapping genes was calculated using the hypergeometric probability formula that considers the total number of genes in the genome. RNA-seq data of sorted $\beta$ and a cells of T2D versus nondiabetic donors (HPAP-RRID:SCR_016202) and of SIX $2^{\mathrm{kd}}$ SC- $\beta$ cells (GEO: GSE147737) (Velazco-Cruz et al. 2020) were analyzed per our data using DESeq2 R package (Love et al. 2014).

\section{$C U T \& R U N$ and library preparation}

Six-hundred-thousand redispersed islet cells were used as input material for each CUT\&RUN, which was performed from three donors, as described (Skene and Henikoff 2017; Hainer et al. 2019|. Briefly, nuclei were extracted with nuclear extraction buffer and added to concanavalin A bead slurries (Polysciences). After blocking, the nuclei/beads were washed in wash buffer and resuspended with rabbit anti-FLAG (Sigma-Millipore F7425) or IgG (Millipore) antibodies overnight at $4^{\circ} \mathrm{C}$. Protein A-micrococcal nuclease (pA-MN; EpiCypher donation) was added to a concentration of 1:400 to nuclei. Cleavage was induced by $100 \mathrm{mM}$ $\mathrm{CaCl}_{2}$ for $30 \mathrm{~min}$ at $0^{\circ} \mathrm{C}$. DNA fragments were released for $20 \mathrm{~min}$ at $37^{\circ} \mathrm{C}$ and purified using phenol/chloroform/isoamyl alcohol followed by chloroform extraction and precipitated with glycogen and ethanol. DNA was resuspended in $0.1 \times$ TE and used for library construction with NEBnext Ultra II library kit. Libraries were sequenced as $2 \times 75$ on HiSeq 4000 .

\section{CUT\&RUN data analysis}

Paired-end reads were trimmed and aligned as per CUT\&RUNtools (Zhu et al. 2019). Briefly, Trimmomatic (Bolger et al. 2014) was used for trimming and Bowtie2 (Langmead and Salzberg 2012) for alignment. HOMER (Heinz et al. 2010) was used for peak calling. Genome browser tracks were generated from mapped reads using the "makeUCSCfile" command. Peaks were called using the "findPeaks" command. The GREAT algorithm was used for gene annotation (McLean et al. 2010). Motifs were identified using the "findMotifs" command. $P$-values for motif enrichment were performed by HOMER software, using a binomial test.

Statistical analysis

For qRT-PCR and GSIS, the number of biological or technical replicates $(n)$, measure of central tendency (e.g., mean), standard deviation, and statistical analysis is detailed in each figure legend. Graphs and statistical analysis were produced and performed using GraphPad Prism (version 8) software.

\section{Data visualization}

Cytometery data were analyzed and graphed using FlowJo software (version 10.8, Beckton, Dickinson, and Company).

Heat maps were made with ComplexHeatmap. Browser tracks were made with the UCSC genome browser. The graphics were made with BioRender. 
Data availability

The data discussed in this publication have been deposited in NCBI's GeneExpression Omnibus (Edgar et al. 2002) and are accessible under accession number GSE164628.

\section{Acknowledgments}

We thank past and current members of the Kim group for advice and encouragement, especially Dr. Y. Hang, Dr. S. Park, and Dr. A. Ibarra Urizar for technical guidance and advice; Dr. C. Chang, Dr. Y. Hang (Kim group), and Dr. R. Bottino (Allegheny Health Network) for assistance in tissue procurement; Dr. M. Angulo (K. Chua group, Stanford) for help with pull-downs and the CUT\&RUN protocol; Dr. G. Oliver (Northwestern University Feinberg School of Medicine) for initial discussions about SIX2 and SIX3; N. Koska for help with antibody testing; and members of the Kim laboratory for comments on the manuscript. We thank Dr. R. Nair (Diabetes Genomics Analysis Core, Stanford Diabetes Research Center) for help with bioinformatics and programming. We thank Professor K. Loh and Professor A. Gloyn for advice and encouragement. We gratefully acknowledge organ donors and their families, and islet procurement through the Alberta Diabetes Institute Islet Core, Integrated Islet Distribution Program (National Institutes of Health UC4 DK098085), the National Disease Research Interchange, and the International Institute for the Advancement of Medicine. R.J.B. was supported by a postdoctoral fellowship from JDRF (3-PDF-2018-584-A-N) and is on leave from Consejo Nacional de Investigaciones Científicas y Técnicas (CONICET)-Universidad de Buenos Aires, Instituto de Investigaciones en Producción Animal (INPA), Buenos Aires, Argentina. H.P. was supported by fellowships from the Maternal and Child Health Research Institute (School of Medicine, Stanford University, UL1TR001085), the American Diabetes Association (1-16-PDF-086), and a Young Investigator Award from the Stanford Institute for Immunity, Transplantation, and Infection; R.L.W. was supported by fellowships from the Division of Endocrinology National Institutes of Health T32 training grant in the Department of Medicine, Stanford University (DK00721741, to A. Hoffman and F. Kraemer) and JDRF (3-PDF-2020-931A-N); and S.K. was supported by a fellowship from the Larry L. Hillblom Foundation (2017-D-008-FEL). Work in the Kim laboratory was supported by the National Institutes of Health (R01 DK107507, R01 DK108817, and U01 DK123743 to S.K.K., and U01 DK123716 to S.K.K. [MPI] and A. Powers [contact PI]), and JDRF Northern California Center of Excellence (to S.K.K. and M. Hebrok). Work here was also supported by National Institutes of Health grant P30 DK1 16074 (to S.K.K.), and by the Stanford Islet Research Core, and Diabetes Genomics and Analysis Core of the Stanford Diabetes Research Center.

Author contributions: R.J.B. and S.K.K. conceptualized the study and directed the work. R.J.B. and S.K.K. were responsible for the methodology. R.J.B., J.Y.L., H.P., R.L.W., S.K., M.S.H.F., and X.G. performed the investigations. R.J.B. and S.K.K. wrote the manuscript with input from all coauthors. S.K.K. supervised the study. R.J.B, R.L.W., H.P., S.K., M.S.H.F., and S.K.K. acquired the funding.

\section{References}

Aguayo-Mazzucato C, Koh A, El Khattabi I, Li W-C, Toschi E, Jermendy A, Juhl K, Mao K, Weir GC, Sharma A, et al. 2011. Mafa expression enhances glucose-responsive insulin secretion in neonatal rat $\beta$ cells. Diabetologia 54: 583-593. doi:10.1007/ s00125-010-2026-z
Allen HL, Flanagan SE, Shaw-Smith C, De Franco E, Akerman I, Caswell R, Ferrer J, Hattersley AT, Ellard S, The International Pancreatic Agenesis Consortium. 2012. GATA6 haploinsufficiency causes pancreatic agenesis in humans. Nat Genet 44: 20-22. doi:10.1038/ng.1035

Arda HE, Li L, Tsai J, Torre EA, Rosli Y, Peiris H, Spitale RC, Dai $\mathrm{C}, \mathrm{Gu} X, \mathrm{Qu} \mathrm{K}$, et al. 2016. Age-dependent pancreatic gene regulation reveals mechanisms governing human $\beta$ cell function. Cell Metab 23: 909-920. doi:10.1016/j.cmet.2016.04.002

Arda HE, Tsai J, Rosli YR, Giresi P, Bottino R, Greenleaf WJ, Chang HY, Kim SK. 2018. A chromatin basis for cell lineage and disease risk in the human pancreas. Cell Syst 7: 310322.e4. doi:10.1016/j.cels.2018.07.007

Artner I, Blanchi B, Raum JC, Guo M, Kaneko T, Cordes S, Sieweke M, Stein R. 2007. Mafb is required for islet $\beta$ cell maturation. Proc Nat1 Acad Sci 104: 3853-3858. doi:10.1073/pnas .0700013104

Artner I, Hang Y, Mazur M, Yamamoto T, Guo M, Lindner J, Magnuson MA, Stein R. 2010. MafA and MafB regulate genes critical to $\beta$-cells in a unique temporal manner. Diabetes 59: 2530-2539. doi:10.2337/db10-0190

Bakken TE, Miller JA, Ding SL, Sunkin SM, Smith KA, Ng L, Szafer A, Dalley RA, Royall JJ, Lemon T, et al. 2016. A comprehensive transcriptional map of primate brain development. Nature 535: 367-375. doi:10.1038/nature 18637

Baron M, Veres A, Wolock SL, Faust AL, Gaujoux R, Vetere A, Ryu JH, Wagner BK, Shen-Orr SS, Klein AM, et al. 2016. A single-cell transcriptomic map of the human and mouse pancreas reveals inter- and intra-cell population structure. Cell Syst 3: 346-360.e4. doi:10.1016/i.cels.2016.08.011

Benner C, van der Meulen T, Cacéres E, Tigyi K, Donaldson CJ, Huising MO. 2014. The transcriptional landscape of mouse $\beta$ cells compared to human $\beta$ cells reveals notable species differences in long non-coding RNA and protein-coding gene expression. BMC Genomics 15: 620. doi:10.1186/1471-2164-15620

Blodgett DM, Nowosielska A, Afik S, Pechhold S, Cura AJ, Kennedy NJ, Kim S, Kucukural A, Davis RJ, Kent SC, et al. 2015. Novel observations from next-generation RNA sequencing of highly purified human adult and fetal islet cell subsets. Diabetes 64: 3172-3181. doi:10.2337/db15-0039

Bolger AM, Lohse M, Usadel B. 2014. Trimmomatic: a flexible trimmer for Illumina sequence data. Bioinformatics 30: 2114-2120. doi:10.1093/bioinformatics/btu170

Camunas-Soler J, Dai XQ, Hang Y, Bautista A, Lyon J, Suzuki K, Kim SK, Quake SR, MacDonald PE. 2020. Patch-seq links single-cell transcriptomes to human islet dysfunction in diabetes. Cell Metab 31: 1017-1031.e4. doi:10.1016/j.cmet.2020 .04 .005 .

Cyphert HA, Walker EM, Hang Y, Dhawan S, Haliyur R, Bonatakis L, Avrahami D, Brissova M, Kaestner KH, Bhushan A, et al. 2019. Examining How the MAFB transcription factor affects islet $\beta$-cell function postnatally. Diabetes 68: 337-348. doi: $10.2337 / \mathrm{db} 18-0903$

Dhawan S, Tschen SI, Zeng C, Guo T, Hebrok M, Matveyenko A, Bhushan A. 2015. DNA methylation directs functional maturation of pancreatic $\beta$ cells. J Clin Invest 125: 2851-2860. doi:10.1172/JCI79956

Dobin A, Davis CA, Schlesinger F, Drenkow J, Zaleski C, Jha S, Batut P, Chaisson M, Gingeras TR. 2013. STAR: ultrafast universal RNA-seq aligner. Bioinformatics 29: 15-21. doi:10 .1093/bioinformatics/bts635

Edgar R, Domrachev M, Lash AE. 2002. Gene Expression Omnibus: NCBI gene expression and hybridization array data 
repository. Nucleic Acids Res 30: 207-210. doi:10.1093/nar/ 30.1.207

Enge M, Arda HE, Mignardi M, Beausang J, Bottino R, Kim SK, Quake SR. 2017. Single-cell analysis of human pancreas reveals transcriptional signatures of aging and somatic mutation patterns. Cell 171: 321-330.e14. doi:10.1016/j.cell.2017.09 .004

Hachiya T, Komaki S, Hasegawa Y, Ohmomo H, Tanno K, Hozawa A, Tamiya G, Yamamoto M, Ogasawara K, Nakamura M, et al. 2017. Genome-wide meta-analysis in Japanese populations identifies novel variants at the TMC6-TMC8 and SIX3-SIX2 loci associated with $\mathrm{HbA}_{1 \mathrm{c}}$. Sci Rep 7: 16147. doi:10.1038/s41598-017-16493-0

Hainer SJ, Bošković A, McCannell KN, Rando OJ, Fazzio TG. 2019. Profiling of pluripotency factors in single cells and early embryos. Cell 177: 1319-1329.e11. doi:10.1016/j.cell.2019.03 .014

He G, Tavella S, Hanley KP, Self M, Oliver G, Grifone R, Hanley N, Ward C, Bobola N. 2010. Inactivation of Six2 in mouse identifies a novel genetic mechanism controlling development and growth of the cranial base. Dev Biol 344: 720-730. doi:10.1016/j.ydbio.2010.05.509

Heinz S, Benner C, Spann N, Bertolino E, Lin YC, Laslo P, Cheng JX, Murre C, Singh H, Glass CK. 2010. Simple combinations of lineage-determining transcription factors prime cis-regulatory elements required for macrophage and B cell identities. Mol Cell 38: 576-589. doi:10.1016/j.molcel.2010.05.004

Helman A, Klochendler A, Azazmeh N, Gabai Y, Horwitz E, Anzi S, Swisa A, Condiotti R, Granit RZ, Nevo Y, et al. 2016. p16Ink4a-induced senescence of pancreatic $\beta$ cells enhances insulin secretion. Nat Med 22: 412-420. doi:10.1038/nm.4054

Huang DW, Sherman BT, Lempicki RA. 2009. Systematic and integrative analysis of large gene lists using DAVID bioinformatics resources. Nat Protoc 4: 44-57. doi:10.1038/nprot .2008 .211

Iacovazzo D, Flanagan SE, Walker E, Quezado R, de Sousa Barros FA, Caswell R, Johnson MB, Wakeling M, Brändle M, Guo M, et al. 2018. MAFA missense mutation causes familial insulinomatosis and diabetes mellitus. Proc Natl Acad Sci 115: 1027-1032. doi:10.1073/pnas.1712262115

Iizuka K, Tomita R, Takeda J, Horikawa Y. 2012. Rat glucagon receptor mRNA is directly regulated by glucose through transactivation of the carbohydrate response element binding protein. Biochem Biophys Res Commun 417: 1107-1112. doi:10.1016/j.bbrc.2011.12.042

Jeong Y, Leskow FC, El-Jaick K, Roessler E, Muenke M, Yocum A, Dubourg C, Li X, Geng X, Oliver G, et al. 2008. Regulation of a remote Shh forebrain enhancer by the Six 3 homeoprotein. Nat Genet 40: 1348-1353. doi:10.1038/ng.230

Karlsson O, Edlund T, Moss JB, Rutter WJ, Walker MD. 1987. A mutational analysis of the insulin gene transcription control region: expression in $\beta$ cells is dependent on two related sequences within the enhancer. Proc Natl Acad Sci 84: 88198823. doi:10.1073/pnas.84.24.8819

Kawakami K, Sato S, Ozaki H, Ikeda K. 2000. Six family genesstructure and function as transcription factors and their roles in development. Bioessays 22: 616-626. doi:10.1002/15211878(200007)22:7<616::AID-BIES4>3.0.CO;2-R

Kim YJ, MAGIC consortium, Go MJ, Hu C, Hong CB, Kim YK, Lee JY, Hwang JY, Oh JH, Kim DJ, et al. 2011. Large-scale genome-wide association studies in East Asians identify new genetic loci influencing metabolic traits. Nat Genet 43: 990995. doi:10.1038/ng.939

Kim S, Whitener RL, Peiris H, Gu X, Chang CA, Lam JY, Camunas-Soler J, Park I, Bevacqua RJ, Tellez K, et al. 2020. Molecu- lar and genetic regulation of pig pancreatic islet cell development. Development 147: dev186213. doi:10.1242/ dev. 186213

Kim-Muller JY, Fan J, Kim YJR, Lee SA, Ishida E, Blaner WS, Accili D. 2016. Aldehyde dehydrogenase 1a3 defines a subset of failing pancreatic $\beta$ cells in diabetic mice. Nat Commun 7: 12631. doi:10.1038/ncomms 12631

Kobayashi M, Goldstein RE, Fujioka M, Paroush Z, Jaynes JB. 2001. Groucho augments the repression of multiple Even skipped target genes in establishing parasegment boundaries. Development 128: 1805-1815.

Kobayashi A, Valerius MT, Mugford JW, Carroll TJ, Self M, Oliver G, McMahon AP. 2008. Six2 defines and regulates a multipotent self-renewing nephron progenitor population throughout mammalian kidney development. Cell Stem Cell 3: 169-181. doi:10.1016/j.stem.2008.05.020

Langmead B, Salzberg SL. 2012. Fast gapped-read alignment with Bowtie 2. Nat Methods 9: 357-359. doi:10.1038/nmeth.1923

Lantz KA, Vatamaniuk MZ, Brestelli JE, Friedman JR, Matschinsky FM, Kaestner KH. 2004. Foxa2 regulates multiple pathways of insulin secretion. J Clin Invest 114: 512-520. doi:10 $.1172 /$ JCI21149

Lemaire K, Thorrez L, Schuit F. 2016. Disallowed and allowed gene expression: two faces of mature islet $\beta$ cells. Annu Rev Nutr 36: 45-71. doi:10.1146/annurev-nutr-071715-050808

Li B, Dewey CN. 2011. RSEM: accurate transcript quantification from RNA-seq data with or without a reference genome. BMC Bioinformatics 12: 323. doi: 10.1186/1471-2105-12-323

Liu W, Lagutin O, Swindell E, Jamrich M, Oliver G. 2010. Neuroretina specification in mouse embryos requires Six3-mediated suppression of Wnt8b in the anterior neural plate. J Clin Investig 120: 3568-3577. doi:10.1172/JCI43219

López-Ríos J, Tessmar K, Loosli F, Wittbrodt J, Bovolenta P. 2003. Six 3 and Six 6 activity is modulated by members of the groucho family. Development 130: 185-195. doi:10.1242/dev .00185

Love MI, Huber W, Anders S. 2014. Moderated estimation of fold change and dispersion for RNA-seq data with DESeq2. Genome Biol 15: 550. doi:10.1186/s13059-014-0550-8

Mandelbaum AD, Kredo-Russo S, Aronowitz D, Myers N, Yanowski E, Klochendler A, Swisa A, Dor Y, Hornstein E. 2019. miR-17-92 and miR-106b-25 clusters regulate $\beta$ cell mitotic checkpoint and insulin secretion in mice. Diabetologia 62: 1653-1666. doi:10.1007/s00125-019-4916-Z

Matschinsky F, Liang Y, Kesavan P, Wang L, Froguel P, Velho G, Cohen D, Permutt M A, Tanizawa Y, Jetton TL. 1993. Glucokinase as pancreatic $\beta$ cell glucose sensor and diabetes gene. I Clin Invest 92: 2092-2098. doi:10.1172/JCI1 16809

McLean CY, Bristor D, Hiller M, Clarke SL, Schaar BT, Lowe CB, Wenger AM, Bejerano G. 2010. GREAT improves functional interpretation of cis-regulatory regions. Nat Biotechnol 28: 495-501. doi:10.1038/nbt.1630

Meier IJ, Butler AE, Saisho Y, Monchamp T, Galasso R, Bhushan A, Rizza RA, Butler PC. 2008. $\beta$-Cell replication is the primary mechanism subserving the postnatal expansion of $\beta$-cell mass in humans. Diabetes 57: 1584-1594. doi:10.2337/db07-1369

Metzger DE, Liu C, Ziaie AS, Naji A, Zaret KS. 2014. Grg3/TLE3 and Grg1/TLE1 induce monohormonal pancreatic $\beta$-cells while repressing a-cell functions. Diabetes 63: 1804-1816. doi:10.2337/db13-0867

Miguel-Escalada I, Bonàs-Guarch S, Cebola I, Ponsa-Cobas J, Mendieta-Esteban J, Atla G, Javierre BM, Rolando DMY, Farabella I, Morgan CC, et al. 2019. Human pancreatic islet three-dimensional chromatin architecture provides insights 
into the genetics of type 2 diabetes. Nat Genet 51: 1137-1148. doi:10.1038/s41588-019-0457-0

Mularoni L, Ramos-Rodríguez M, Pasquali L. 2017. The pancreatic islet regulome browser. Front Genet 8: 13. doi:10.3389/ fgene.2017.00013

Muraro MJ, Dharmadhikari G, Grün D, Groen N, Dielen T, Jansen E, van Gurp L, Engelse MA, Carlotti F, de Koning EJP, et al. 2016. A single-cell transcriptome atlas of the human pancreas. Cell Syst 3: 385-394.e3. doi:10.1016/j.cels.2016.09 .002

Nair GG, Liu JS, Russ HA, Tran S, Saxton MS, Chen R, Juang C, Li M-L, Nguyen VQ, Giacometti S, et al. 2019. Recapitulating endocrine cell clustering in culture promotes maturation of human stem-cell-derived $\beta$ cells. Nat Cell Biol 21: 263-274. doi:10.1038/s41556-018-0271-4

O'Brien LL, Guo Q, Lee Y, Tran T, Benazet J-D, Whitney PH, Valouev A, McMahon AP. 2016. Differential regulation of mouse and human nephron progenitors by the Six family of transcriptional regulators. Development 143: 595-608. doi:10.1242/dev.127175

Park JS, Ma W, O'Brien LL, Chung E, Guo JJ, Cheng JG, Todd Valerius M, McMahon JA, Wong WH, McMahon AP. 2012. Six2 and Wnt regulate self-renewal and commitment of nephron progenitors through shared gene regulatory networks. Dev Cell 23: 637-651. doi:10.1016/j.devcel.2012.07.008

Patel KA, Kettunen J, Laakso M, Stančáková A, Laver TW, Colclough K, Johnson MB, Abramowicz M, Groop L, Miettinen PJ, et al. 2017. Heterozygous RFX6 protein truncating variants are associated with MODY with reduced penetrance. Nat Commun 8: 888. doi:10.1038/s41467-017-00895-9

Peiris H, Park S, Louis S, Gu X, Lam JY, Asplund O, Ippolito GC, Bottino R, Groop L, Tucker H, et al. 2018. Discovering human diabetes-risk gene function with genetics and physiological assays. Nat Commun 9: 3855. doi:10.1038/s41467-01806249-3

Pullen TJ, Khan AM, Barton G, Butcher SA, Sun G, Rutter GA. 2010. Identification of genes selectively disallowed in the pancreatic islet. Islets 2: 89-95. doi:10.4161/isl.2.2.11025

Puri S, Roy N, Russ HA, Leonhardt L, French EK, Roy R, Bengtsson H, Scott DK, Stewart AF, Hebrok M. 2018. Replication confers $\beta$ cell immaturity. Nat Commun 9: 485. doi:10 .1038/s41467-018-02939-0

Qiu WL, Zhang YW, Feng Y, Li LC, Yang L, Xu CR. 2018. Deciphering pancreatic islet $\beta$ cell and $\alpha$ cell maturation pathways and characteristic features at the single-cell level. Cell Metab 27: 702. doi:10.1016/j.cmet.2018.01.017

Reinert RB, Cai Q, Hong JY, Plank JL, Aamodt K, Prasad N, Aramandla R, Dai C, Levy SE, Pozzi A, et al. 2014. Vascular endothelial grow th factor coordinates islet innervation via vascular scaffolding. Development 141: 1480-1491. doi:10.1242/dev .098657

Schaffer AE, Taylor BL, Benthuysen JR, Liu J, Thorel F, Yuan W, Jiao Y, Kaestner KH, Herrera PL, Magnuson MA, et al. 2013. Nkx6.1 controls a gene regulatory network required for establishing and maintaining pancreatic $\beta$ cell identity. PLoS Genet 9: e1003274. doi:10.1371/journal.pgen.1003274

Scharp DW, Downing R, Merrell RC, Greider M. 1980. Isolating the elusive islet. Diabetes 29 Suppl 1: 19-30. doi:10.2337/ diab.29.1.S19

Segerstolpe Å, Palasantza A, Eliasson P, Andersson E-M, Andréasson A-C, Sun X, Picelli S, Sabirsh A, Clausen M, Bjursell MK, et al. 2016. Single-cell transcriptome profiling of human pancreatic islets in health and type 2 diabetes. Cell Metab 24: 593-607. doi:10.1016/j.cmet.2016.08.020
Self M, Geng X, Oliver G. 2009. Six2 activity is required for the formation of the mammalian pyloric sphincter. Dev Biol 334: 409-417. doi:10.1016/j.ydbio.2009.07.039

Sellick GS, Barker KT, Stolte-Dijkstra I, Fleischmann C, Coleman RJ, Garrett C, Gloyn AL, Edghill EL, Hattersley AT, Wellauer PK, et al. 2004. Mutations in PTF1A cause pancreatic and cerebellar agenesis. Nat Genet 36: 1301-1305. doi:10.1038/ ng1475

Skene PJ, Henikoff S. 2017. An efficient targeted nuclease strategy for high-resolution mapping of DNA binding sites. Elife 6: e21856. doi:10.7554/eLife.21856

Sneddon JB, Tang Q, Stock P, Bluestone JA, Roy S, Desai T, Hebrok M. 2018. Stem cell therapies for treating diabetes: progress and remaining challenges. Cell Stem Cell 22: 810-823. doi:10.1016/j.stem.2018.05.016

Spracklen CN, Shi J, Vadlamudi S, Wu Y, Zou M, Raulerson CK, Davis JP, Zeynalzadeh M, Jackson K, Yuan W, et al. 2018. Identification and functional analysis of glycemic trait loci in the China health and nutrition survey. PLoS Genet 14: e1007275. doi:10.1371/journal.pgen.1007275

Spracklen CN, Horikoshi M, Kim YJ, Lin K, Bragg F, Moon S, Suzuki K, Tam CHT, Tabara Y, Kwak S-H, et al. 2020. Identification of type 2 diabetes loci in 433,540 East Asian individuals. Nature 582: 240-245. doi:10.1038/s41586-0202263-3

Suh CS, Ellingsen S, Austbø L, Zhao X-F, Seo H-C, Fjose A. 2010. Autoregulatory binding sites in the zebrafish six $3 a$ promoter region define a new recognition sequence for Six 3 proteins. FEBS I 277: 1761-1775. doi:10.1111/j.1742-4658 $.2010 .07599 . \mathrm{x}$

Svendsen B, Larsen O, Gabe MBN, Christiansen CB, Rosenkilde MM, Drucker DJ, Holst JJ. 2018. Insulin secretion depends on intra-islet glucagon signaling. Cell Rep 25: 1127-1134.e2. doi:10.1016/j.celrep.2018.10.018

Teta M, Long SY, Wartschow LM, Rankin MM, Kushner JA. 2005. Very slow turnover of $\beta$-cells in aged adult mice. Diabetes 54: 2557-2567. doi:10.2337/diabetes.54.9.2557

Thurner M, van de Bunt M, Torres JM, Mahajan A, Nylander V, Bennett AJ, Gaulton KJ, Barrett A, Burrows C, Bell CG, et al. 2018. Integration of human pancreatic islet genomic data refines regulatory mechanisms at type 2 diabetes susceptibility loci. Elife 7: e31977. doi:10.7554/eLife.31977

Tze WJ, Tai J. 1982. Preparation of pseudoislets for morphological and functional studies. Transplantation 34: 228-231. doi:10 .1097/00007890-198210000-00019

Urakami T. 2019. Maturity-onset diabetes of the young (MODY): current perspectives on diagnosis and treatment. Diabetes Metab Syndr Obes 12: 1047-1056. doi:10.2147/DMSO .S179793

Varshney A, Scott LJ, Welch RP, Erdos MR, Chines PS, Narisu N, Albanus RD, Orchard P, Wolford BN, Kursawe R, et al. 2017. Genetic regulatory signatures underlying islet gene expression and type 2 diabetes. Proc Natl Acad Sci 114: 23012306. doi:10.1073/pnas.1621192114

Velazco-Cruz L, Goedegebuure MM, Maxwell KG, Augsornworawat $\mathrm{P}$, Hogrebe NJ, Millman JR. 2020. SIX2 regulates human $\beta$ cell differentiation from stem cells and functional maturation in vitro. Cell Rep 31: 107687. doi:10.1016/j.celrep.2020 .107687

Veres A, Faust AL, Bushnell HL, Engquist EN, Kenty JHR, Harb G, Poh YC, Sintov E, Gürtler M, Pagliuca FW, et al. 2019. Charting cellular identity during human in vitro $\beta$-cell differentiation. Nature 569: 368-373. doi:10.1038/s41586-019$1168-5$ 
Wang YJ, Golson ML, Schug J, Traum D, Liu C, Vivek K, Dorrell C, Naji A, Powers AC, Chang KM, et al. 2016a. Single-cell mass cytometry analysis of the human endocrine pancreas. Cell Metab 24: 616-626. doi:10.1016/j.cmet.2016.09.007

Wang YJ, Schug J, Won KJ, Liu C, Naji A, Avrahami D, Golson ML, Kaestner KH. 2016b. Single-cell transcriptomics of the human endocrine pancreas. Diabetes 65: 3028-3038. doi:10 .2337/db16-0405

Yoshihara E, Wei Z, Lin CS, Fang S, Ahmadian M, Kida Y, Tseng T, Dai Y, Yu RT, Liddle C, et al. 2016. ERR $\gamma$ Is required for the metabolic maturation of therapeutically functional glucose- responsive $\beta$ cells. Cell Metab 23: 622-634. doi:10.1016/j .cmet.2016.03.005

Zeng C, Mulas F, Sui Y, Guan T, Miller N, Tan Y, Liu F, Jin W, Carrano AC, Huising MO, et al. 2017. Pseudotemporal ordering of single cells reveals metabolic control of postnatal $\beta$ cell proliferation. Cell Metab 25: 1160-1175.e11. doi:10.1016/j .cmet.2017.04.014

Zhu Q, Liu N, Orkin SH, Yuan G-C. 2019. CUT\&RUNTools: a flexible pipeline for CUT\&RUN processing and footprint analysis. Genome Biol 20: 192. doi:10.1186/s13059-0191802-4 


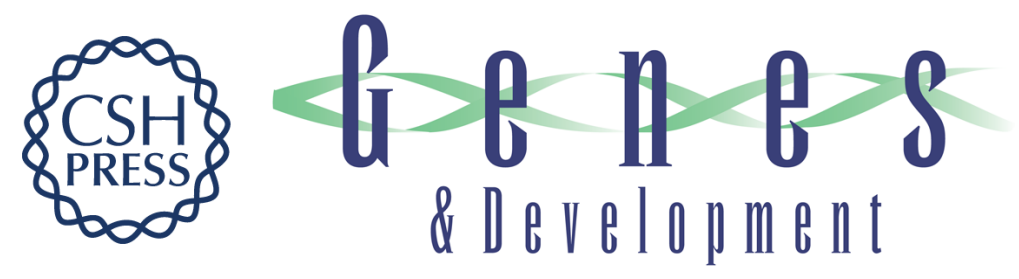

\section{SIX2 and SIX3 coordinately regulate functional maturity and fate of human pancreatic $\beta$ cells}

Romina J. Bevacqua, Jonathan Y. Lam, Heshan Peiris, et al.

Genes Dev. 2021, 35: originally published online January 14, 2021

Access the most recent version at doi:10.1101/gad.342378.120

\section{Supplemental http://genesdev.cshlp.org/content/suppl/2021/01/13/gad.342378.120.DC1 Material}

References This article cites 80 articles, 17 of which can be accessed free at: http://genesdev.cshlp.org/content/35/3-4/234.full.html\#ref-list-1

Creative This article is distributed exclusively by Cold Spring Harbor Laboratory Press for the first Commons six months after the full-issue publication date (see

License http://genesdev.cshlp.org/site/misc/terms.xhtml). After six months, it is available under a Creative Commons License (Attribution-NonCommercial 4.0 International), as described at http://creativecommons.org/licenses/by-nc/4.0/.

Email Alerting Receive free email alerts when new articles cite this article - sign up in the box at the top Service right corner of the article or click here.

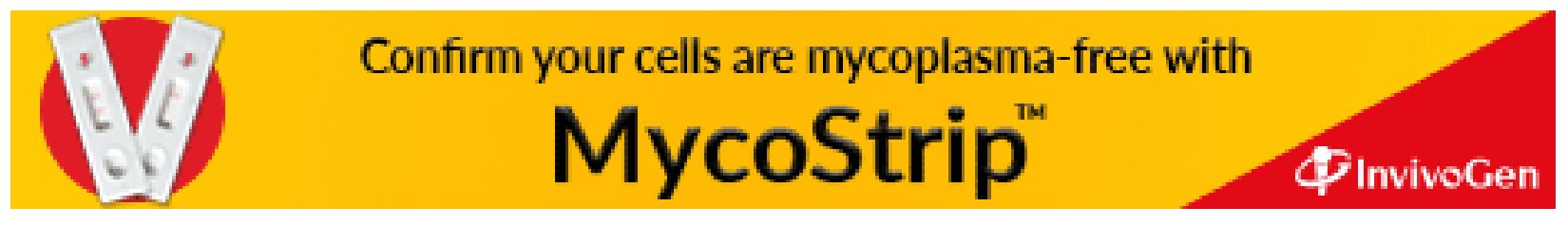

